\title{
Analysis of Weather Conditions for Aerial Security and Optimization in Maroua-Salak
}

\author{
Daïka Augustin 1,2, Igri Moudi Pascal'3,4, Mounabbahou Mal Oumarou1, Mbane Biouele Cesar² \\ ${ }^{1}$ Department of Meteorology and Climatology, National Advanced School of Engineering, University of Maroua, Maroua, Cameroon \\ ${ }^{2}$ Laboratory of Earth's Atmosphere Physics, Faculty of Science, University of Yaoundé 1, Yaoundé, Cameroon \\ ${ }^{3}$ Climate Application and Prediction Centre of Central Africa (CAPC-AC), Douala, Cameroon \\ ${ }^{4}$ Laboratory of Environmental Modeling and Atmospheric Physics, Department of Physics, Faculty of Science, University of \\ Yaoundé 1, Yaoundé, Cameroon \\ Email: moudipascal@yahoo.fr, augustindaika@yahoo.fr
}

How to cite this paper: Augustin, D., Pascal, I.M., Oumarou, M.M. and Cesar, M.B. (2022) Analysis of Weather Conditions for Aerial Security and Optimization in Maroua-Salak. Atmospheric and Climate Sciences, 12, 172-188. https://doi.org/10.4236/acs.2022.121012

Received: October 29, 2021

Accepted: January 25, 2022

Published: January 28, 2022

Copyright ( 2022 by author(s) and Scientific Research Publishing Inc. This work is licensed under the Creative Commons Attribution International License (CC BY 4.0).

http://creativecommons.org/licenses/by/4.0/

\section{(c) (i) Open Access}

\begin{abstract}
In this study, the weather conditions of the accident at Maroua-Salak airport on 02 August 2020 are analyzed. This C130 aircraft accident took place under bad weather conditions. This bad weather is diagnosed using the models as CFS, GFS and GEFS that reanalyze outputs of the results. At the end of this re-analysis, the result obtained shows that the event which took place at the Maroua-Salak airport was predictable. However, the analysis of these results has made it possible to present the rainfall cumul between 05 and $10 \mathrm{~mm}$ for this day. In addition, a comparative study of the rainfall cumul obtained by the CFS, GFS and GEFS models and that estimated by the satellites has been carried out. These models can significantly improve the prevention of such disasters in the region.
\end{abstract}

\section{Keywords}

Weather Conditions, Maroua-Salak Airport, Models, Rainfall Cumul

\section{Introduction}

Maroua-Salak International Airport is an adequate infrastructure to effectively intervene in risk management and emergencies. It is located in the municipality of Maroua $1^{\text {st }}$, Diamaré Division, in the Far North Cameroon region and is located between $10^{\circ} 27^{\prime} 05^{\prime \prime}$ North Latitude and $14^{\circ} 15^{\prime} 26^{\prime \prime}$ Longitude East. The airport recorded an aircraft (the C130 aircraft) on 02 August 2020. This accident is due to "a particularly difficult weather" [1].

African airports are often in a state of expanded decay. The landing tracks are not always well maintained and signaling is often non-existent. Security at air- 
ports of seventeen African countries, including Cameroon, is ensured by the Agency for Air Navigation Security in Africa and Madagascar (ASECNA). But most of these airports are technically poorly equipped, with the absence of radars [2] [3]. However, the C130 type aircraft is equipped with a meteorological radar. This article aims to analyze, focusing on the C130 aircraft accident of 02 August 2020, the weather conditions in relation with the aerial security and optimization in Maroua-Salak, a city characterized by its geographical position particular and climatology of thunderstorms and electrical activities. It aims to reduce the impacts of hazardous weather phenomena. To situate this work in context, it seemed useful to deepen the output analysis of the numerical forecast models (CFS, GFS and GEFS models) of time on the large scale and at the synoptic scale to determine the potentially stable and unstable areas. It also needed us to develop the Alert Weather Bulletin (vigilance card) of the day. The study focuses only on the Far North region of Cameroon; But, given its geographical location, the presence of the Squall lines and the West African monsoon, it seemed useful to examine the synoptic situation and analyze the average fields of the various weather parameters in relation to Weather phenomena.

\section{Study Area, Data and Methods}

\subsection{Study Area}

Our study area is located in the Diamaré Division, Far North region of Cameroon. This Division is one of six (6) Divisions that make up the Far North region and is bounded to the north by Logone and Chari Division, north-west by the Mayo Sava Division, west by the Mayo Tsanaga Division, east by Mayo-Danay Division, and south by Mayo-Kani Division (see Figure 1). IL is located in the
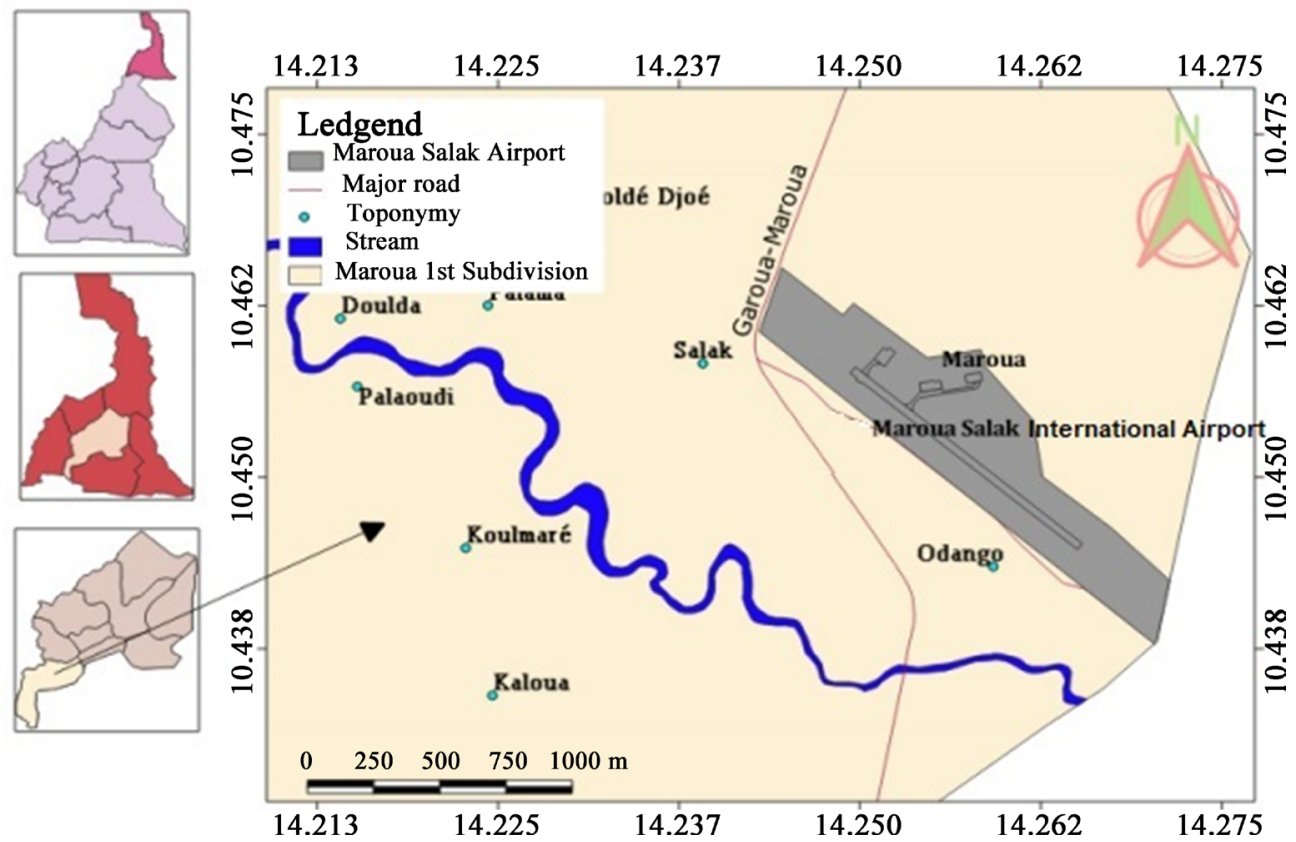

Figure 1. Map of the study area. 
Diamaré plain, which rests in the West of the Mandara Mountains $(1700 \mathrm{~m})$ and slopes gently (3\%) in the east of the Chad basin. Its climate is Sudano-Sahelian type characterized by two seasons: a rainy season (the rainfall is unevenly distributed in time and space and usually lasts 4 to 5 months) and a dry season lasting 7 to 8 months. Its temperatures are around $25^{\circ} \mathrm{C}$ in cool season, from $30^{\circ} \mathrm{C}$ in the rainy season and peak at $45^{\circ} \mathrm{C}$ in periods of high heat. The moisture content is between $30 \%$ and $35 \%$. But the more one goes to the north; over the climate is harsh [4]. Its floors are very diverse.

\subsection{Data and Methods}

The CFS (Climate Forecast System) model is a seasonal model developed by the National Centers for Environmental Prediction (NCEP) and NOAA. It takes into account the situations of the past and statistics of evolution, El Nino, the Nina, the North Atlantic oscillation or the evolution of the air masses of the last weeks [5] [6]. The atmospheric data of the CFS model measured (ground stations, radiosonders, satellites) are irregularly distributed over time and space and serve to generate the initial conditions. These data are assimilated by complex calculations and thanks to super-computers on a virtual, three-dimensional, regular time initialization grid $t_{0}$, covering the entire earth and are analyzed 4 times a day at $00 \mathrm{Z}, 06 \mathrm{Z}, 12 \mathrm{Z}$ and $18 \mathrm{Z}$ [7]. Thanks to other super-computers, GFS calculates and simulates the evolution of weather parameters (winds, temperatures, pressures, humidity, cape, precipitation, etc.) taking into account the laws of fluid physics. It finally produced the results for each point of the grid distributed over the entire globe. The results are contained in available Grib files.

The Global Forecast System Ensemble (GEFS) is one of the most important components of NOAA's Operational Environmental Forecast Operational Systems since its implementation in 1993. The GEFS forecasting competence has been significantly improved since then, benefiting from bets level of the initial disturbance generation of the set, a higher resolution of the model and larger size of the set [8]. The horizontal resolution of the GEFS passes between about $52 \mathrm{~km}$ for the first 8 days of the forecast and about $70 \mathrm{~km}$ for the next 8 days at around $34 \mathrm{~km}$ and $52 \mathrm{~km}$, respectively [9].

\section{Results and Discussions}

\subsection{Analysis of CFS, GFS and GEFS Models}

\subsubsection{Analysis of Large-Scale Weather Parameters}

1) Sea Surface Temperature

Figure 2 presents the forecast of the sea surface temperature for the week of July 27 to 02 August 2020 by the CFS model. It shows that the temperature increases on the African coast in the last observations. This means, we can get along with possible convective precipitation.

\section{2) Equatorial Waves}

For the week of July 27 to August 02, 2020, the CFS model provided for the 
presence of different waves on the Central Africa sub region. On this model exit, the presence of a tropical depression (low) covers the Far North region of Cameroon, southern Chad and the center of Sudan; it is also the Rossby wave Equatorial which governs northern Sudan and also the presence of the MJO on Chad and East of Niger (Figure 3).

For that day, in addition to the waves that have been observing, we notice that there has been the appearance of a Kelvin wave.
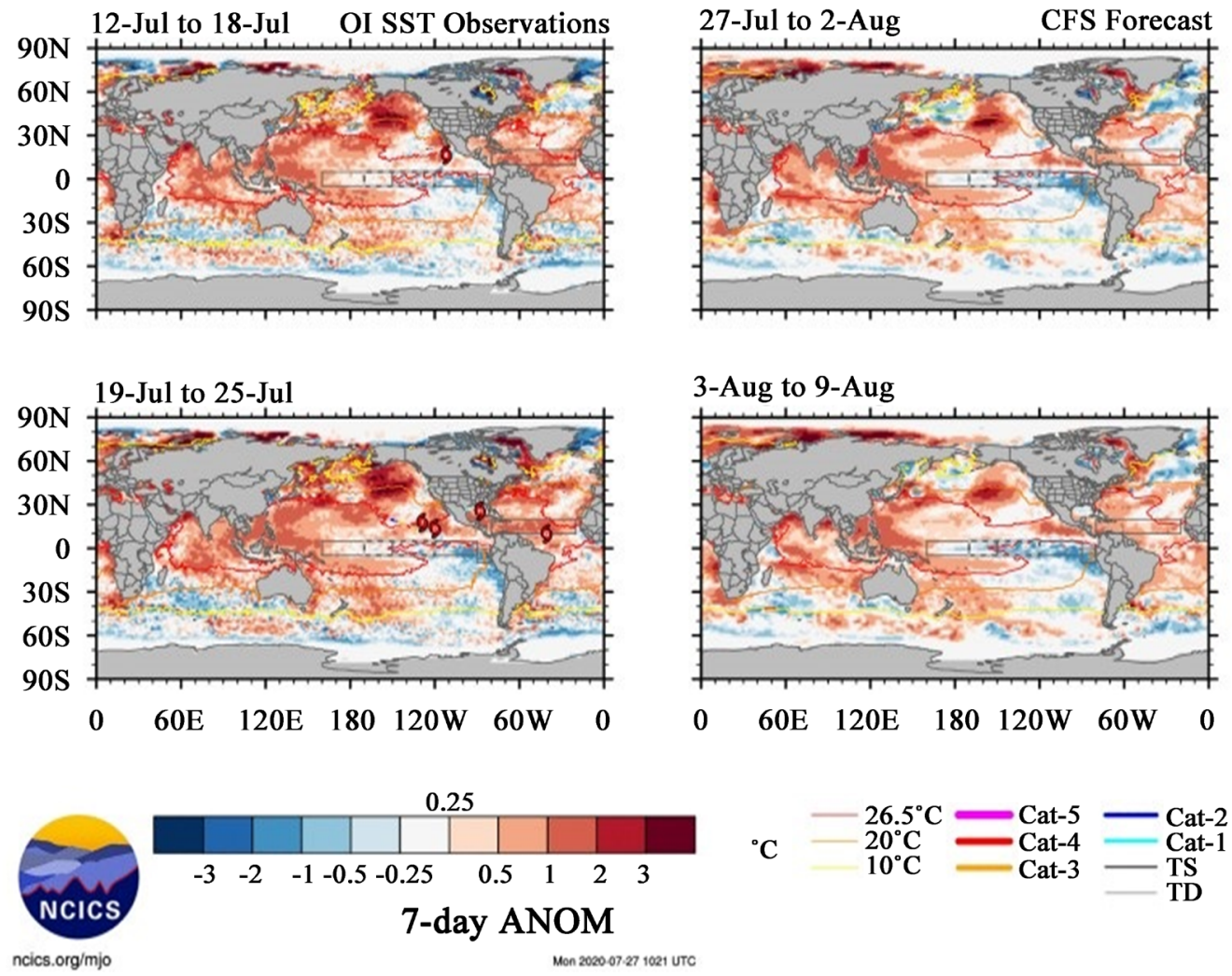

Figure 2. Forecasting the SST by the CFS model (NCICS.org).

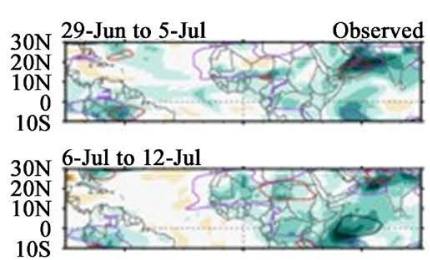

27-Jul to 2-Aug
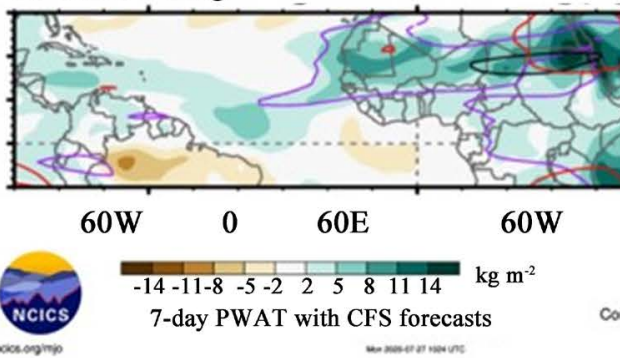

60W $0 \quad 60 \mathrm{E}$

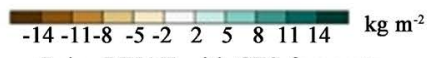

7-day PWAT with CFS forecasts

nomerem nom

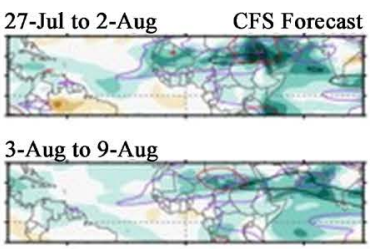

CFS Forecast

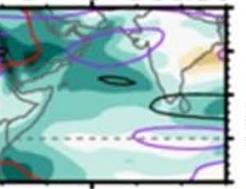

$60 \mathrm{~W}$
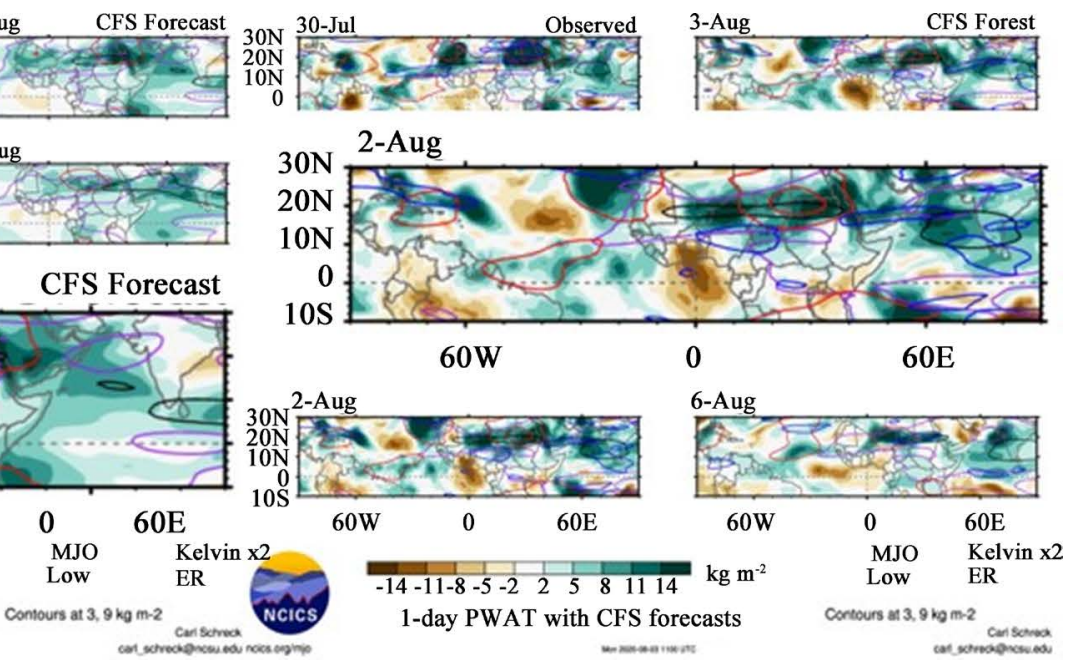

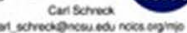

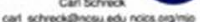

Figure 3. Planned and observed waves (NCICS.org). 


\subsubsection{Analysis of Synoptic Weather Parameters}

\section{1) Pressure field}

The model has provided a low-pressure being in the Sahel-Saharan area (Figure 4). From 12 UTC onwards, the center of action which is north of Chad amplify while that of the DRC weakens.

\section{2) Wind flow}

The wind flow distribution provided at $850 \mathrm{hPa}$ by the model reveals the cyclonic configurations for the four days in advance of the day of 02 August 2020. In Figure 5(a), at 00 UTC, one identifies theses configurations in western Sudan with strong penetration of the southern trade winds as the days approach. In addition, we also note the birth vortex cyclone in the center of Niger. At 06 UTC, the confluence line in the center of Chad intensifies and the disturbance is growing (Figure 5(b)). At 12 UTC, the system multiplies and the confluence line intensifies southern Chad (Figure 5(c)). At 18 UTC, the new system comes into play and the former ends (Figure 5(d)).

The model has provided a displacement of the wind flow from 700HPA to 00 UTC and 06 UTC (Figure 6(a) and Figure 6(b)). In Figure 6(a) and Figure 6(b), we note that at this level the flow is not laminar; it is which marks the presence of an east wave and the Talweg along with South Chad. This wave defines the trajectory of the East-West system. At 12 UTC to 18 UTC, the confluence line at this level is strengthened (Figure 6(c) and Figure 6(d)).

\section{3) Moisture}

Figure 7 (a) shows that the moisture provided by the model in the layer $850 \_500$ to 00 UTC is $70 \%$ to $80 \%$ which can maintain the system, and the maximum of the humidity is found in eastern Chad more precisely in the area where we have been located our disturbance (80\%). It is noted that moisture in the 850_500 HPA layer at 06 UTC has undergone an increase in the layer (Figure 7(b)). The model also shows that an increase in humidity in the layer at 12 UTC of which a large amount of humidity is at least $80 \%$ (Figure $7(\mathrm{c})$ ) and a decrease to 18 UTC in some areas (Figure 7(d)).

Figure 8(a) shows that at the $700 \mathrm{hPa}$ level at $00 \mathrm{UTC}$, the maximum humidity
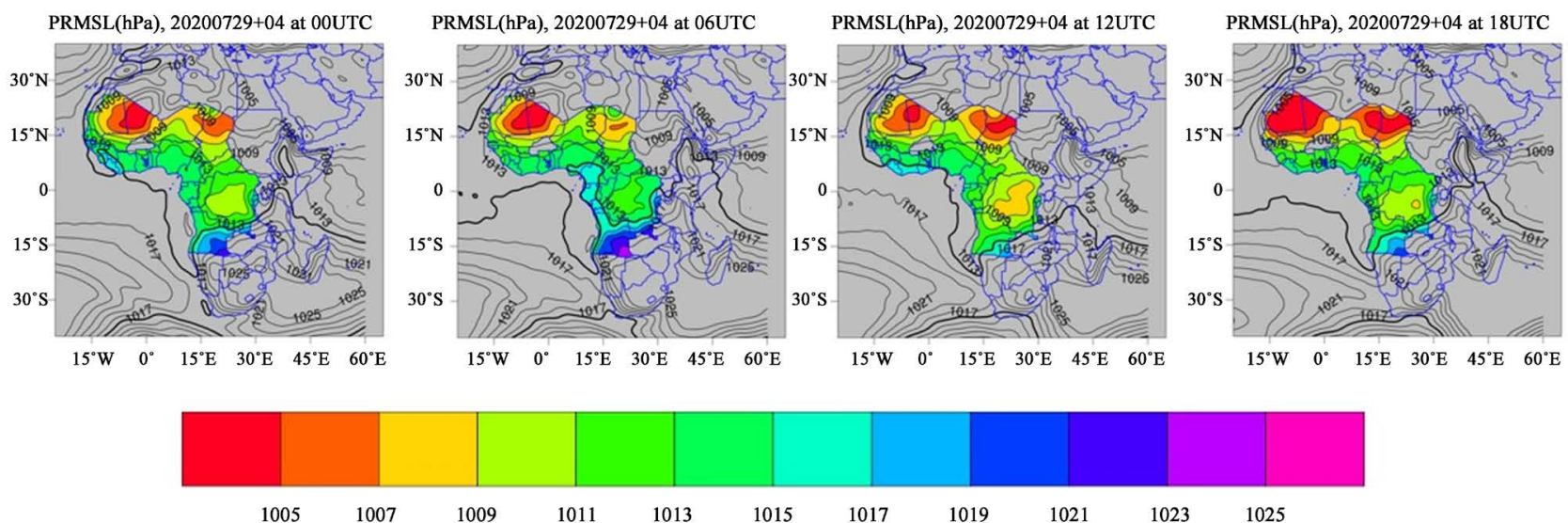

Figure 4. Reduced sea level pressure for the day of 02 August 2020. 
(a) $30^{\circ} \mathrm{N} 850 \mathrm{hPa}, 20200729+04$ at $00 \mathrm{UTC}$

$850 \mathrm{hPa}, 20200730+03$ at $00 \mathrm{UTC}$

$850 \mathrm{hPa}, 20200731+02$ at $00 \mathrm{UTC}$
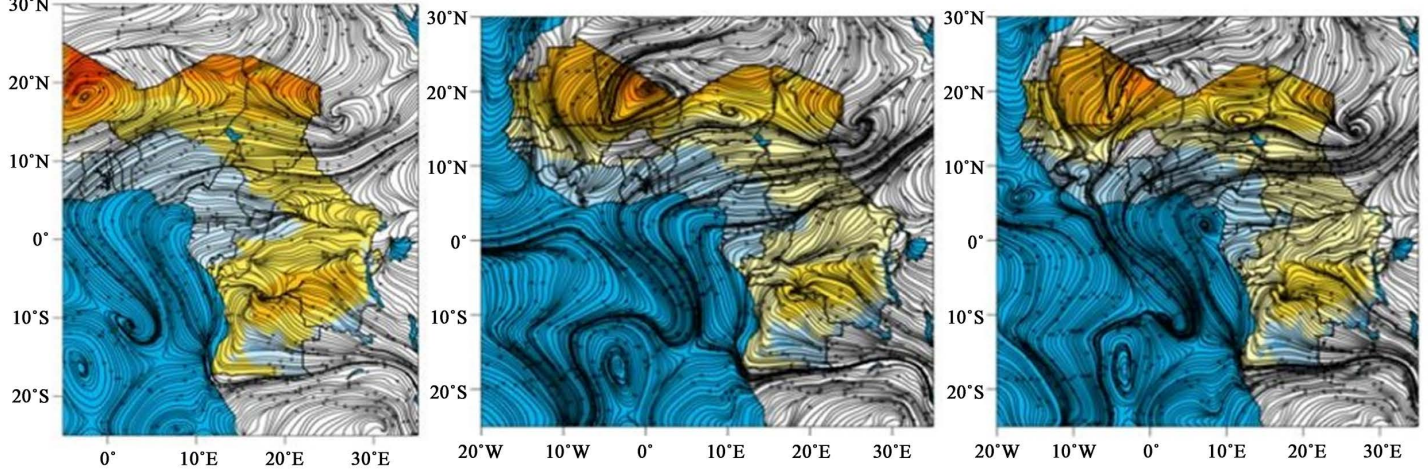

(b) $850 \mathrm{hPa}, 20200729+04$ at $06 \mathrm{UTC}$

$850 \mathrm{hPa}, 20200730+03$ at $06 \mathrm{UTC}$
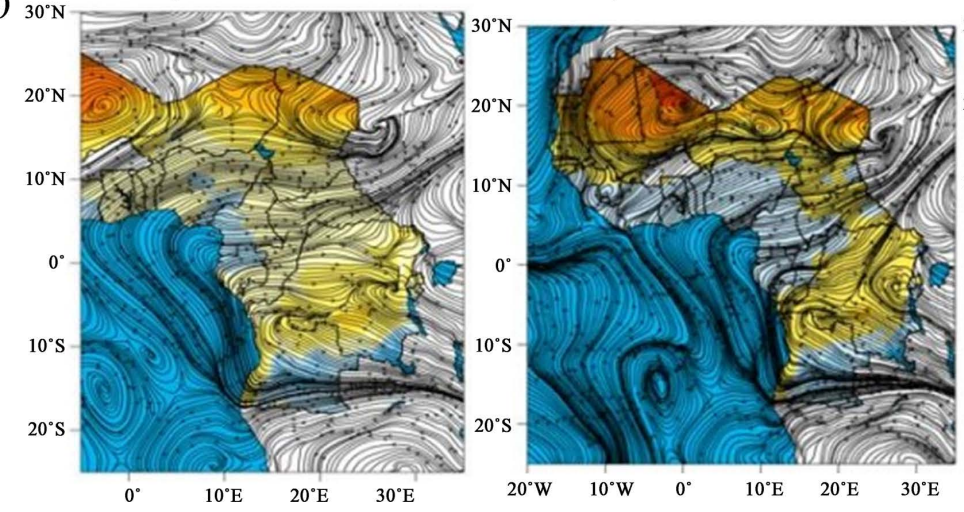

$850 \mathrm{hPa}, 20200731+02$ at $06 \mathrm{UTC}$

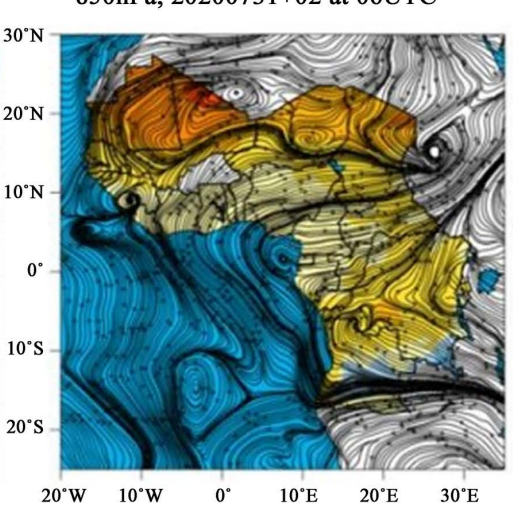

(c) $850 \mathrm{hPa}, 20200729+04$ at $12 \mathrm{UTC}$

$850 \mathrm{hPa}, 20200730+03$ at $12 \mathrm{UTC}$

$850 \mathrm{hPa}, 20200731+02$ at $12 \mathrm{UTC}$
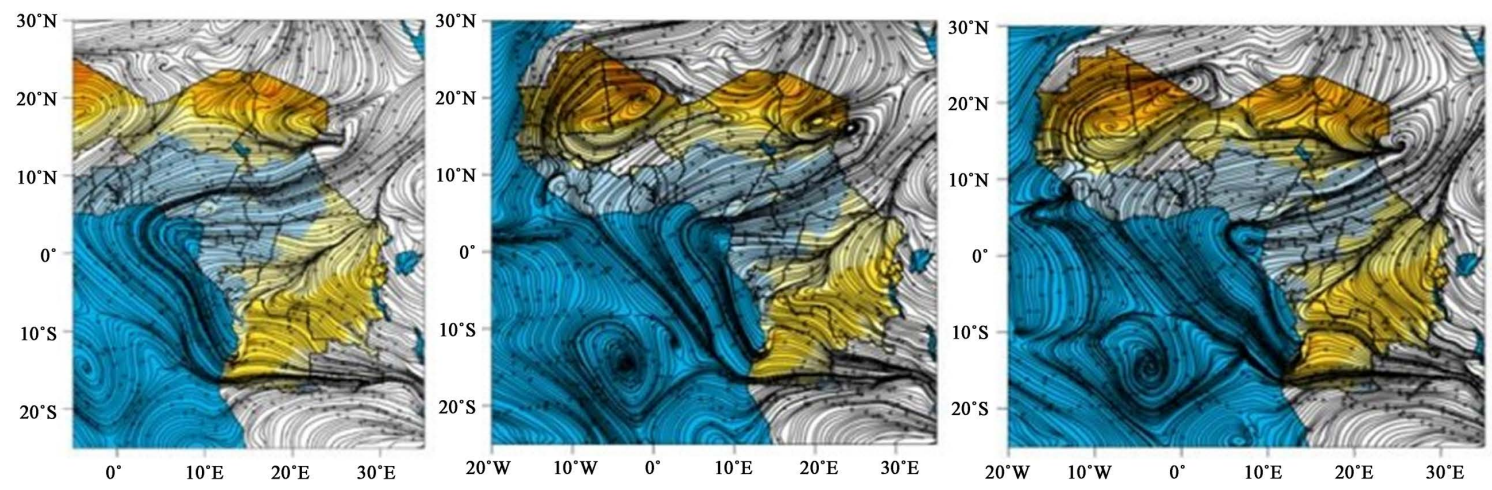

(d) 30

$850 \mathrm{hPa}, 20200729+04$ at $18 \mathrm{UTC}$

$850 \mathrm{hPa}, 20200730+03$ at $18 \mathrm{UTC}$

$850 \mathrm{hPa}, 20200731+02$ at $18 \mathrm{UTC}$
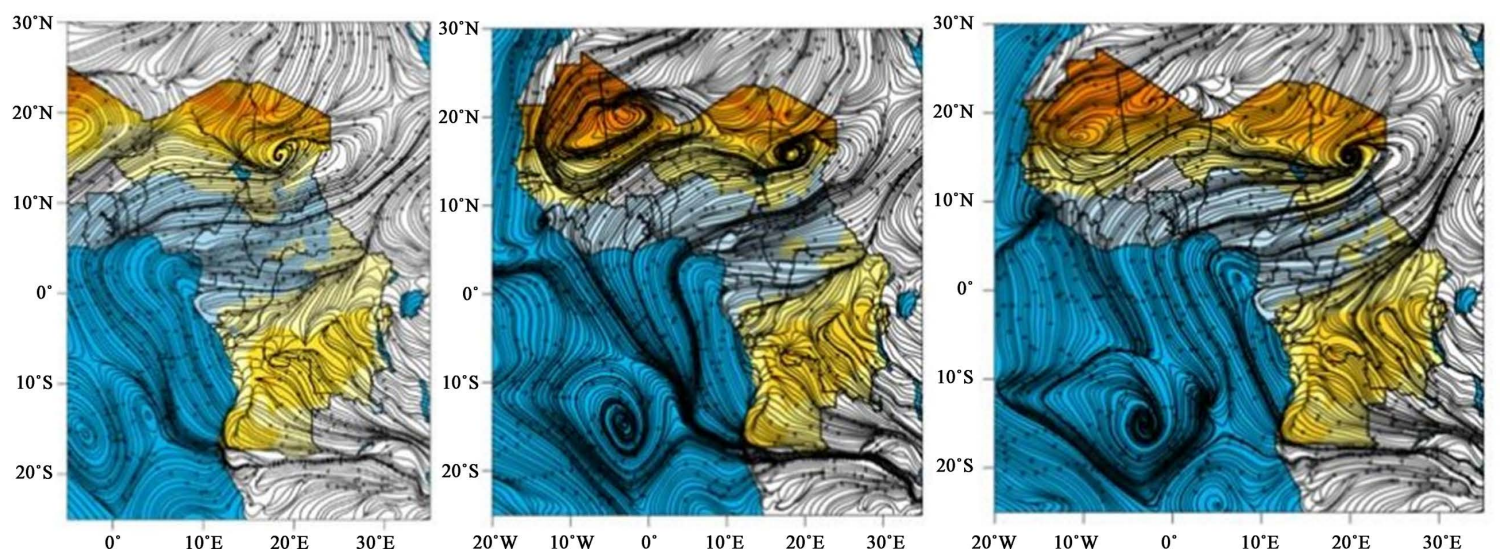

Figure 5. Wind flow at $850 \mathrm{HPA}$ level at $00 \mathrm{UTC}$ (a), 06 UTC (b), 12 UTC (c) and 18 UTC (d). 
(a) $30^{\circ} \mathrm{N} 00 \mathrm{hPa}, 20200729+04$ at $00 \mathrm{UTC}$

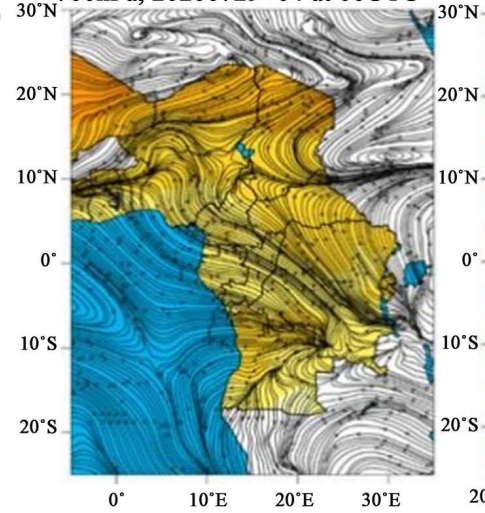

(b)

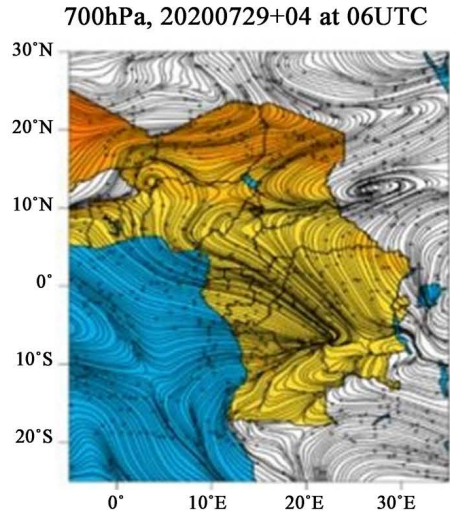

$700 \mathrm{hPa}, 20200730+03$ at $00 \mathrm{UTC}$

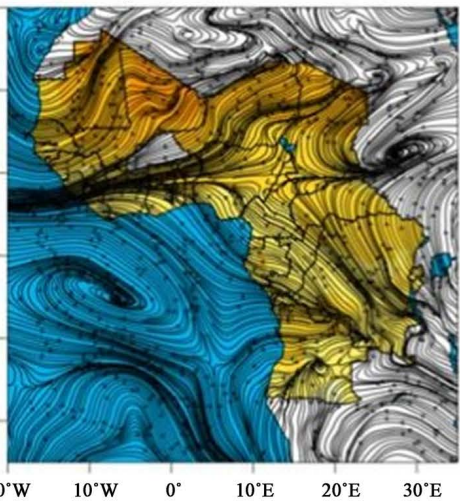

$700 \mathrm{hPa}, 20200730+03$ at $06 \mathrm{UTC}$

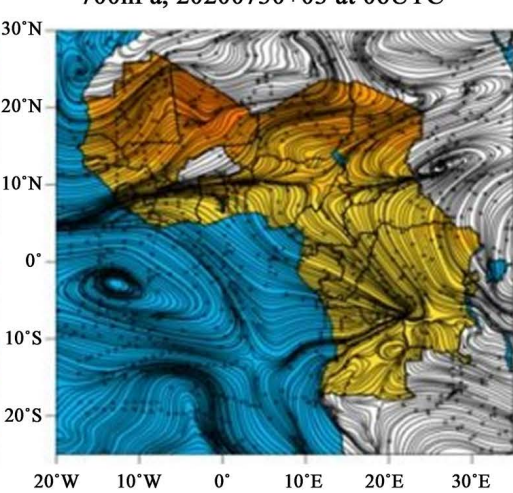

$700 \mathrm{hPa}, 20200730+03$ at $12 \mathrm{UTC}$

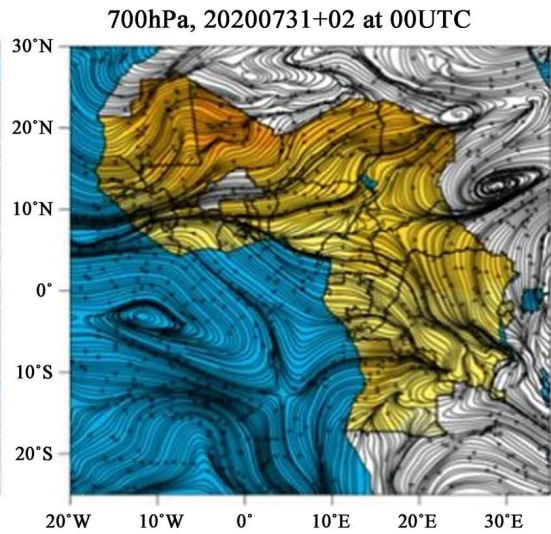

$700 \mathrm{hPa}, 20200731+02$ at $06 \mathrm{UTC}$

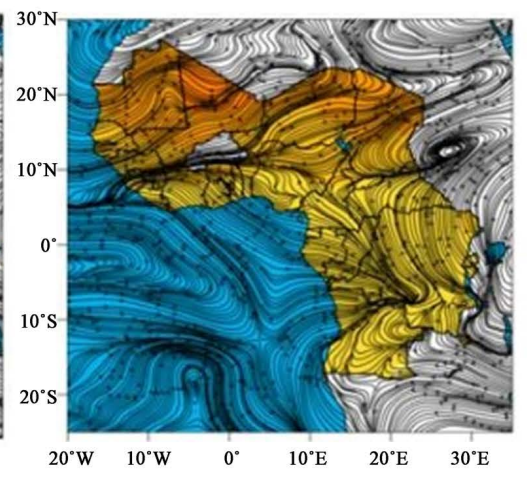

$700 \mathrm{hPa}, 20200731+02$ at $12 \mathrm{UTC}$

\section{(c) $30^{\circ} \mathrm{N}$}
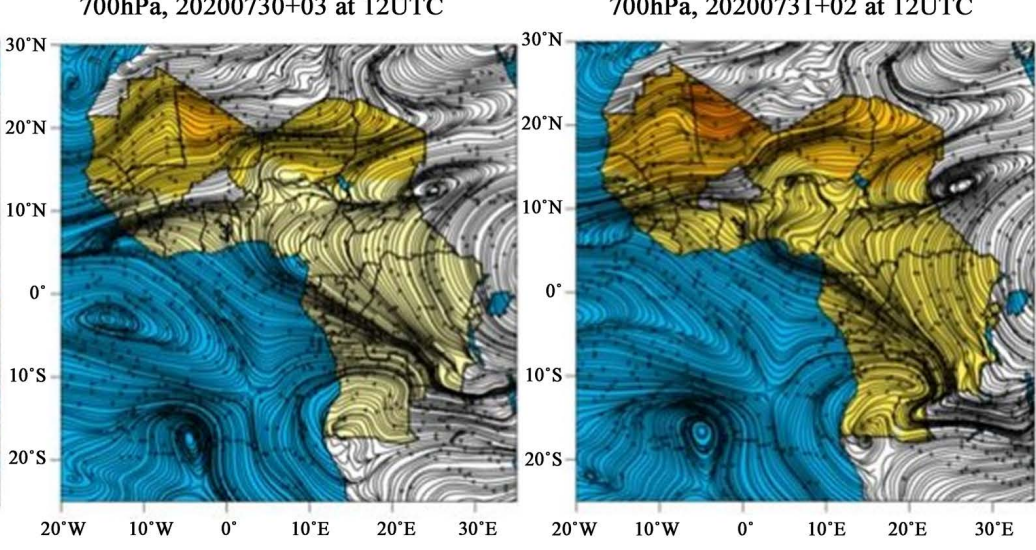

(d)

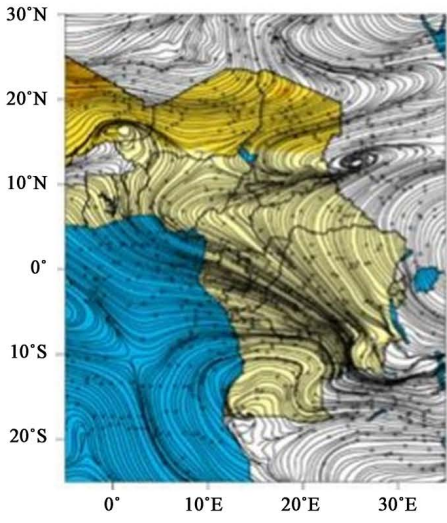

$700 \mathrm{hPa}, 20200730+03$ at $18 \mathrm{UTC}$

$700 \mathrm{hPa}, 20200731+02$ at $18 \mathrm{UTC}$

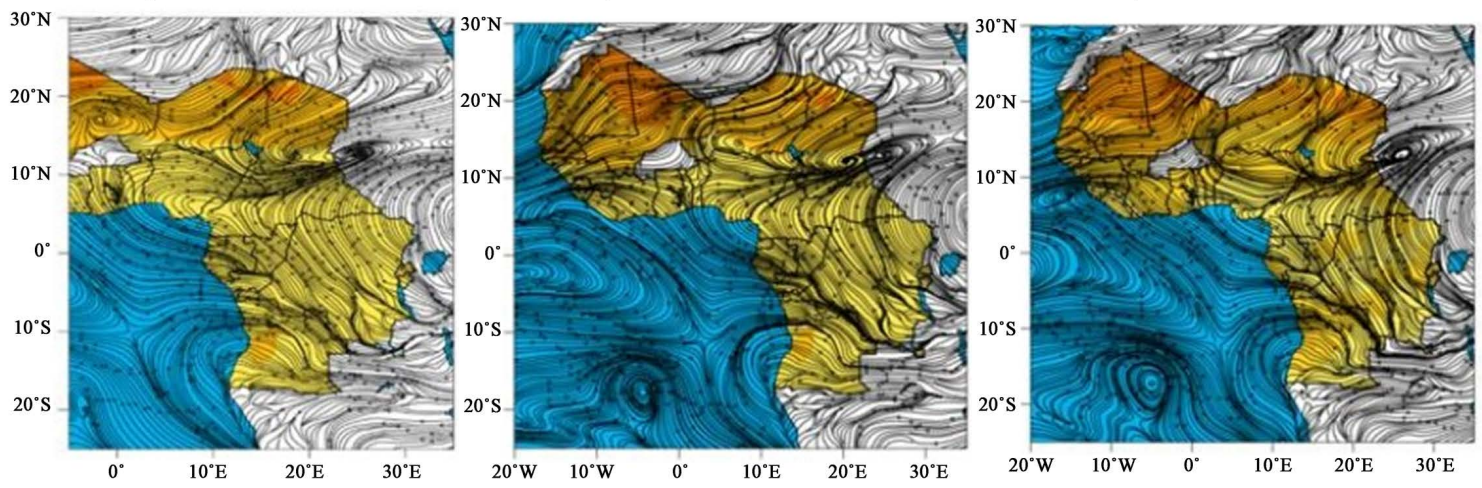

Figure 6. Wind flow at $700 \mathrm{hPa}$ level at 00 UTC (a), 06 UTC (b), 12 UTC (c) and 18 UTC (d). 

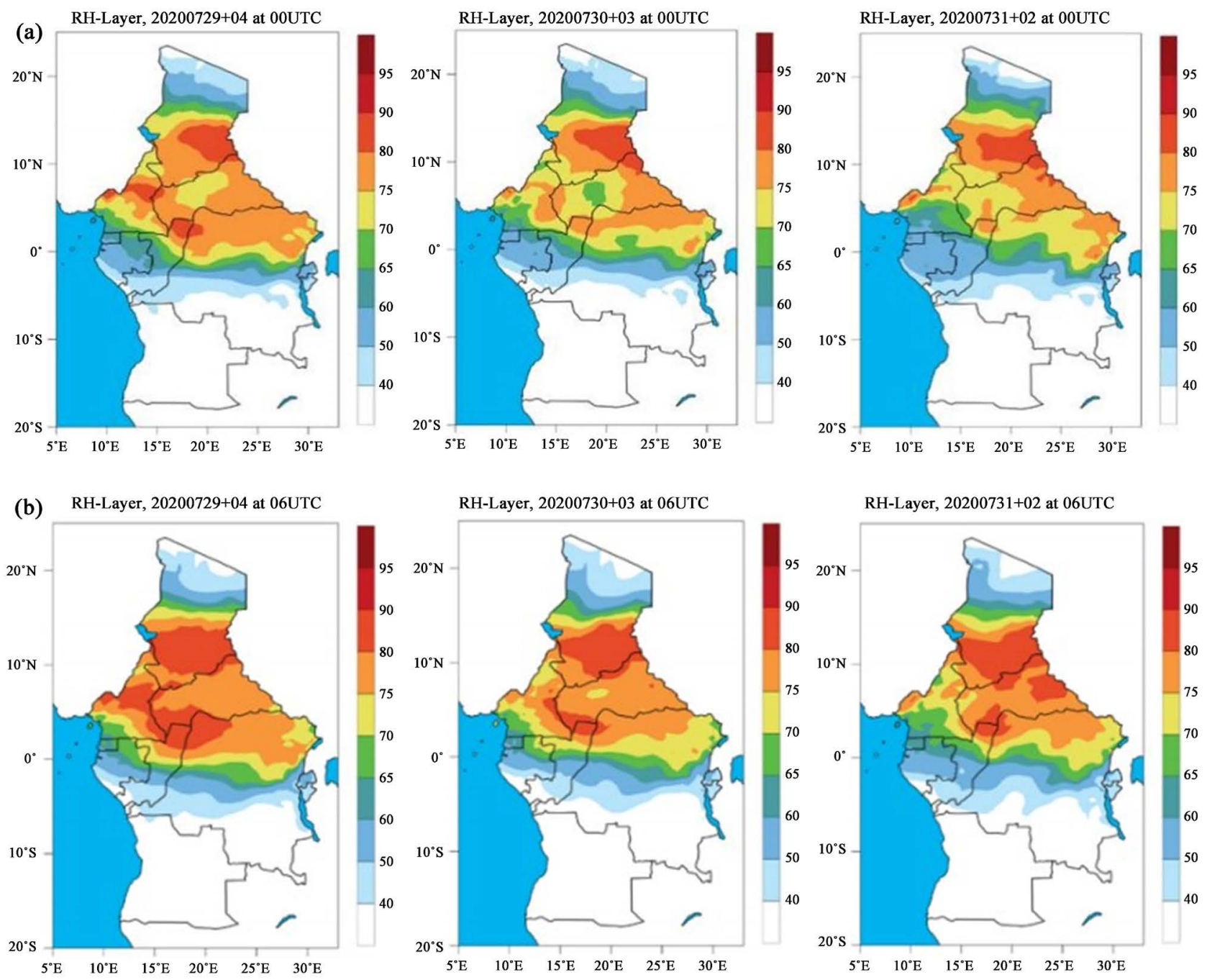

(c) RH-Layer, 20200729+04 at 12UTC
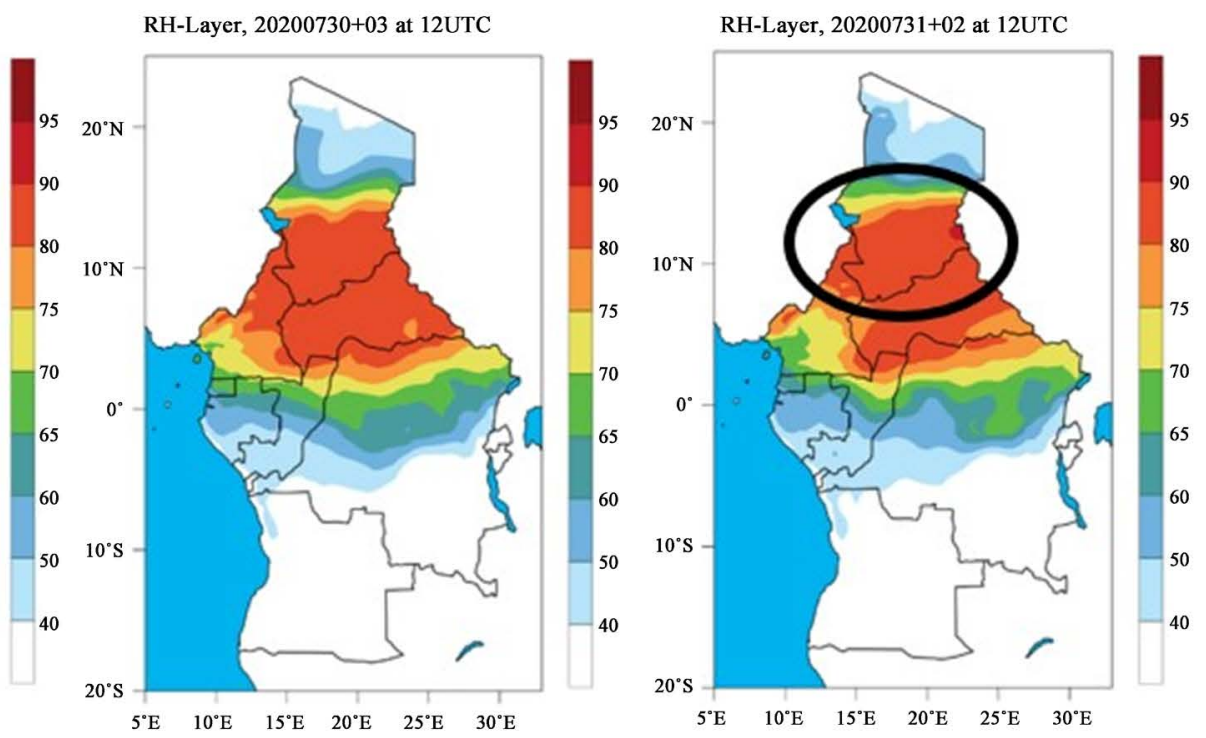

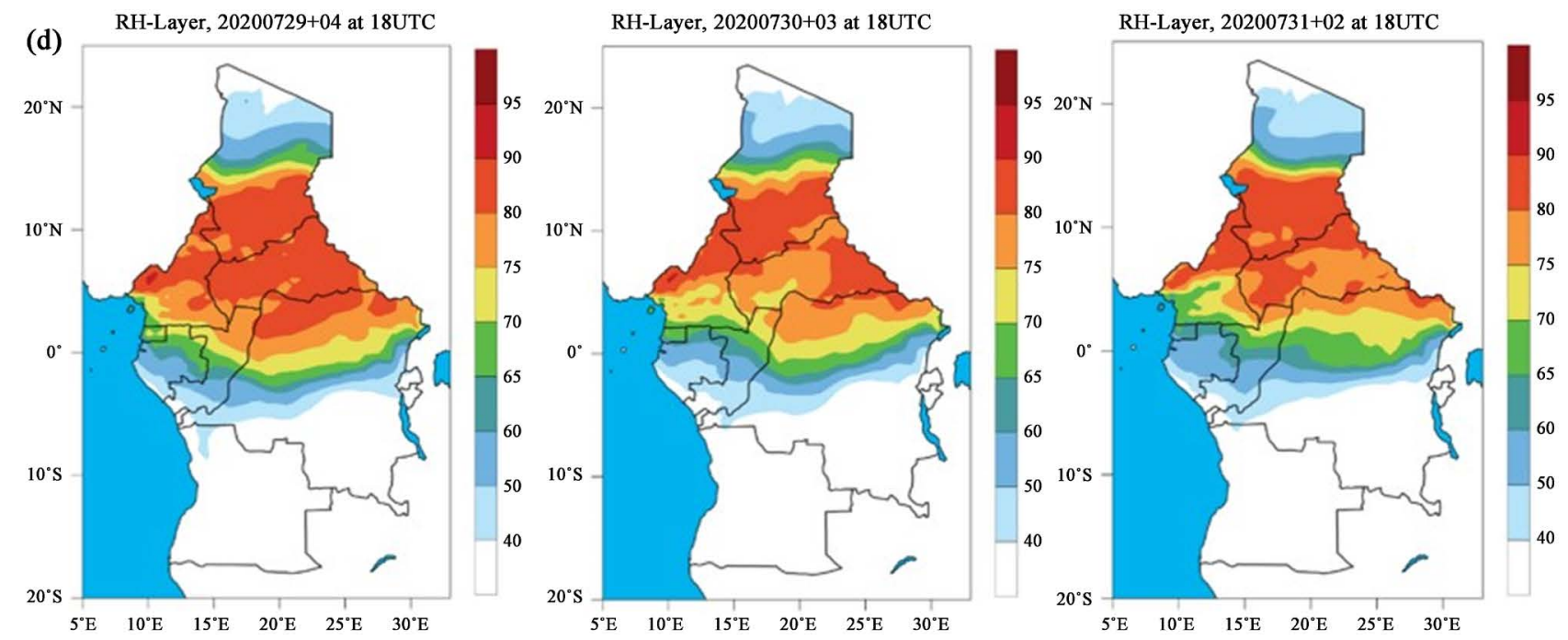

Figure 7. Moisture in layer 850_500 hPa at 00 UTC (a), 06 UTC (b), 12 UTC(c) and 18 UTC (d).

$(>80 \%)$ is found in southern Chad and in the Far North region of Cameroon, it is found with a humidity of 70\%. At 06 UTC, the model has provided a moisture growth in the north of the Far North region of Cameroon (Figure 8(b)). The humidity is increasing and rising from $70 \%$ to $80 \%$ towards the South of the Far North from 12 UTC (Figure 8(c)) to 18 UTC (Figure 8(d))

\section{4) Convective Available Potential Energy (CAPE)}

Figure 9 presents a low available convection energy provided by the model to be able to generate convections in the period between 00 UTC and 06 UTC (Figure 9(a) and Figure 9(b)). In the Far North region, this energy is less than $500 \mathrm{~J} / \mathrm{Kg}$. At $12 \mathrm{UTC}$, this energy increases slightly up to $18 \mathrm{UTC}$ and expects a value of $800 \mathrm{~J} / \mathrm{Kg}$ at $18 \mathrm{UTC}$ towards the South-East (Figure 9(c) and Figure 9(d)).

\section{5) Precipitable Water (PWAT)}

Figure 10 illustrates a large quantity of precipitable water (PWAT) between 00 UTC and 06 UTC which is located in central Chad $\left(>55 \mathrm{Kg} / \mathrm{m}^{2}\right.$ significant threshold) this that is provided by the model. In the Far North, this quantity varies from 45 to $50 \mathrm{~kg} / \mathrm{m}^{2}$ from South to North.

Figure 11 shows Precipitable Water (PWAT) between 12 UTC and 18 UTC, there is an increase in the amount of precipitable water in the region and covers part of the Far North region of Cameroon whose figures have increased has reached $55 \mathrm{Kg} / \mathrm{m}^{2}$.

For the day of August 2, 2020, heavy rains are forecast by the model in eastern Chad $(100 \mathrm{~mm})$, the average covers central Chad $(>50 \mathrm{~mm})$ and weak towards the Far North of Cameroon ( 1 to $13 \mathrm{~mm}$ ) and variable in the Far North region (Figure 12).

Figure 13 shows the total precipitation forecast by the model up to $00+1$ UTC for the day of August 02. The maximum is found in eastern Chad (100 $\mathrm{mm})$ and an average towards western Cameroon $(50 \mathrm{~mm})$. 

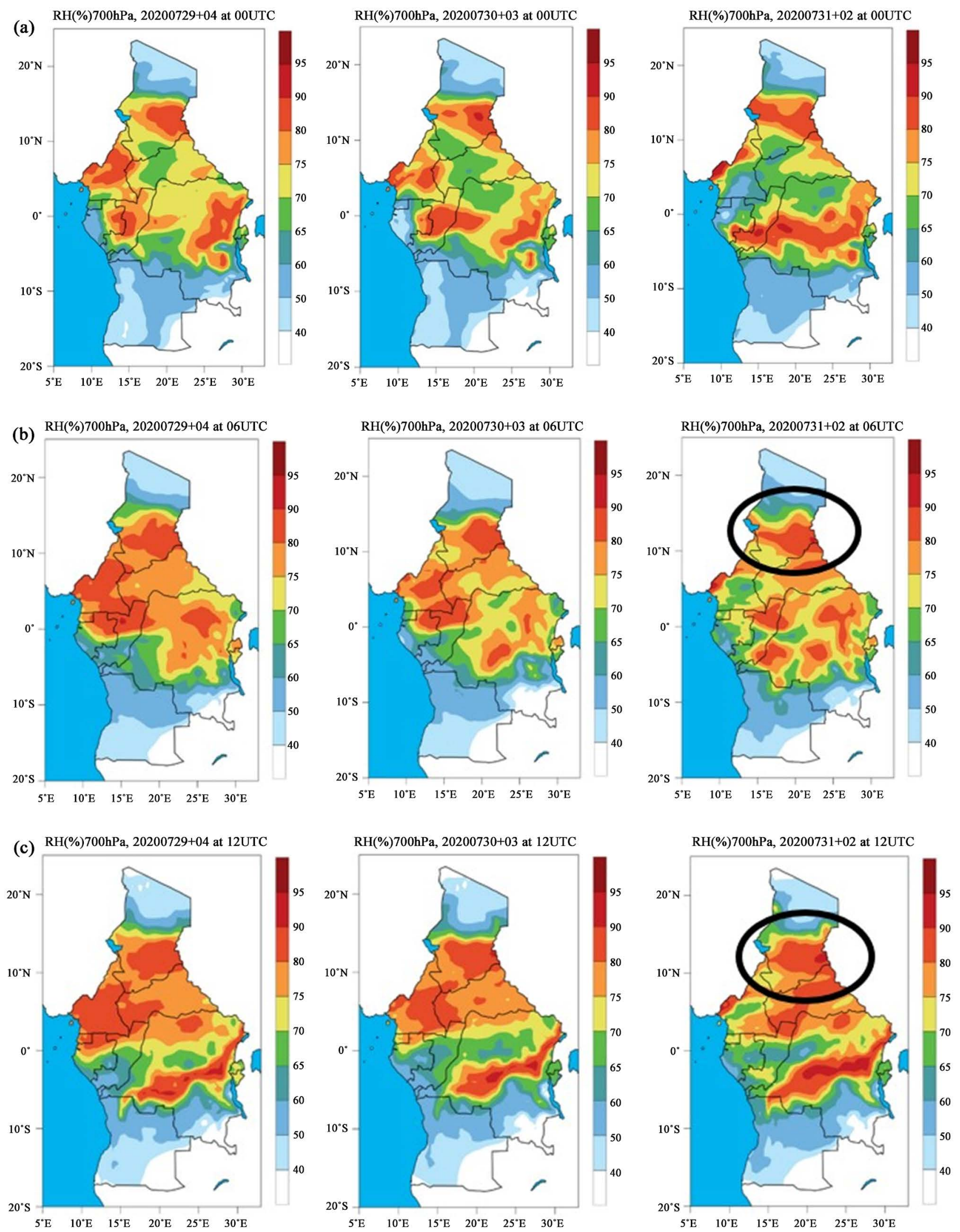

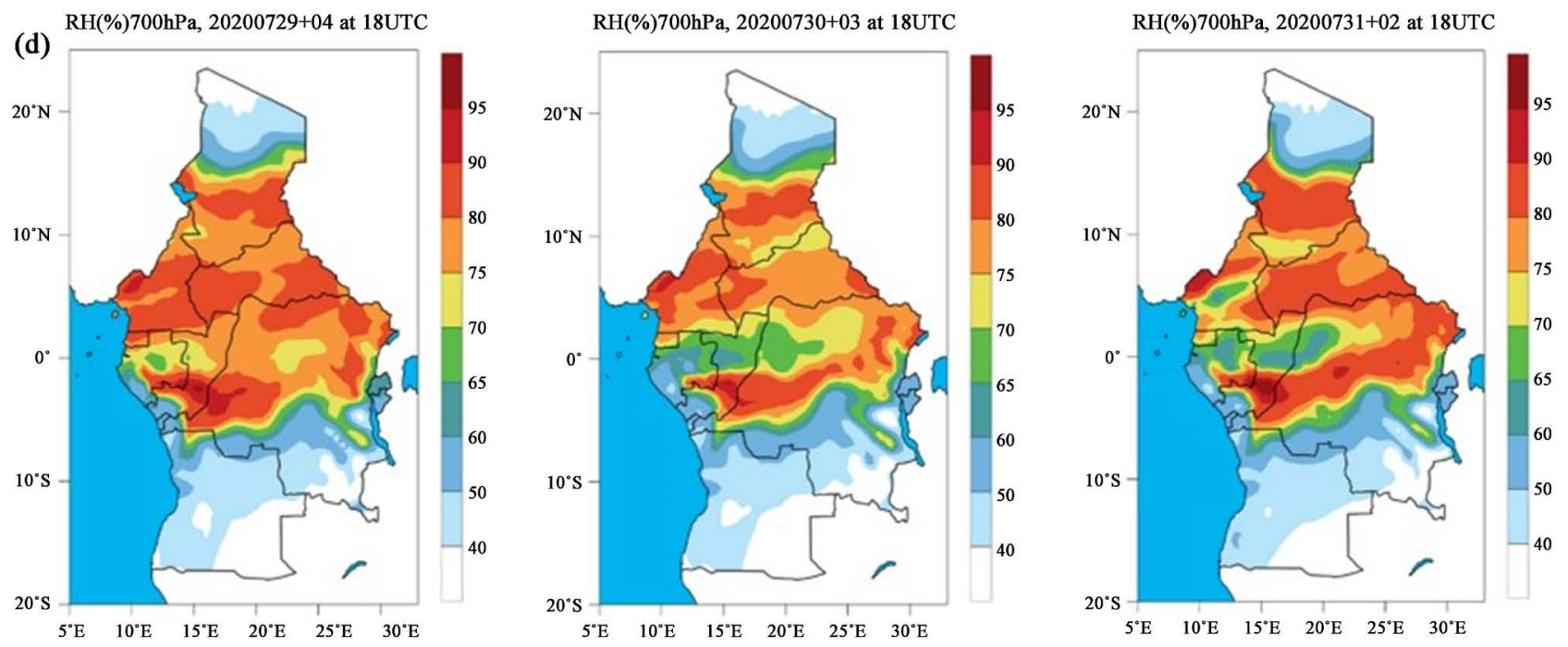

Figure 8. Humidity at $700 \mathrm{hPa}$ level at $00 \mathrm{UTC}$ (a), 06 UTC (b), 12 UTC (c) and 18 UTC (d).

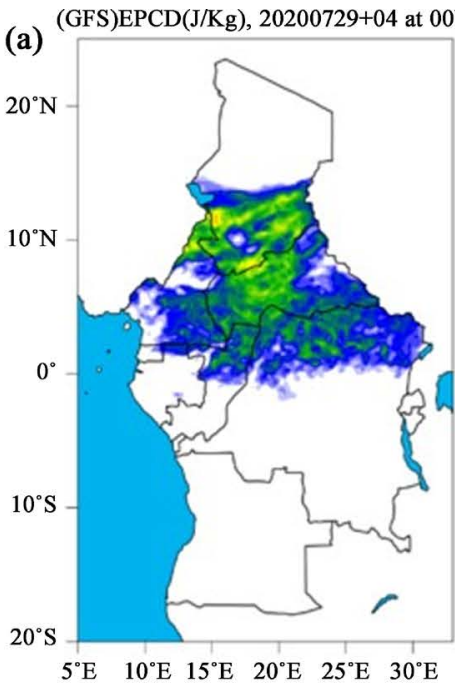

(b) (GFS)EPCD(J/Kg), 20200729+04 at 06UTC

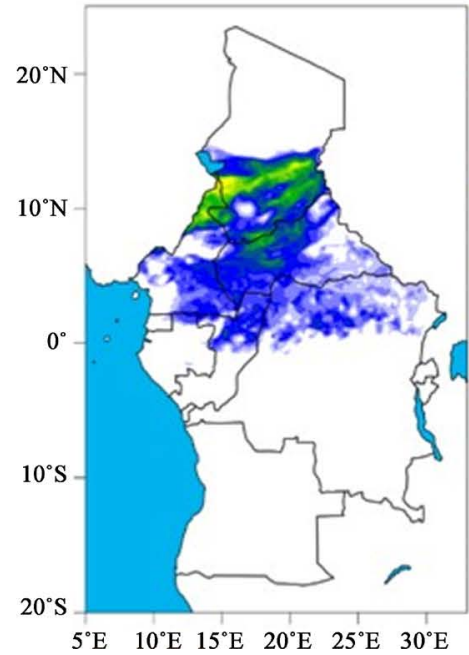

(GFS)EPCD(J/Kg), 20200730+03 at 00UTC

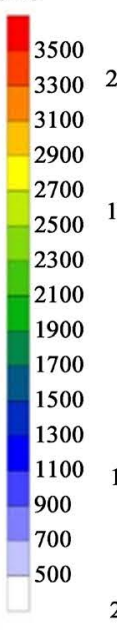

$20^{\circ} \mathrm{S}$

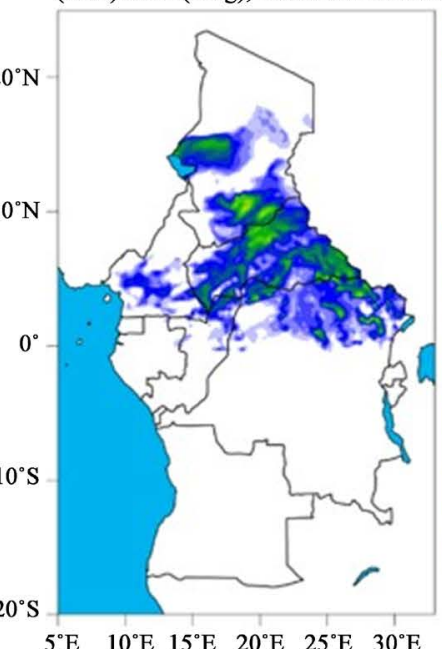

(GFS)EPCD(J/Kg), 20200730+03 at 06UTC

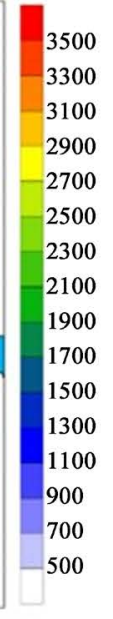

$20^{\circ}$

$5^{\circ} \mathrm{E} \quad 10^{\circ} \mathrm{E} \quad 15^{\circ} \mathrm{E} \quad 20^{\circ} \mathrm{E} \quad 25^{\circ} \mathrm{E} \quad 30^{\circ} \mathrm{E}$

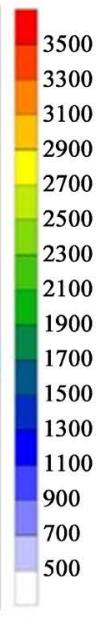

$20^{\circ} \mathrm{S}$

(GFS)EPCD(J/Kg), 20200731+02 at 00UTC

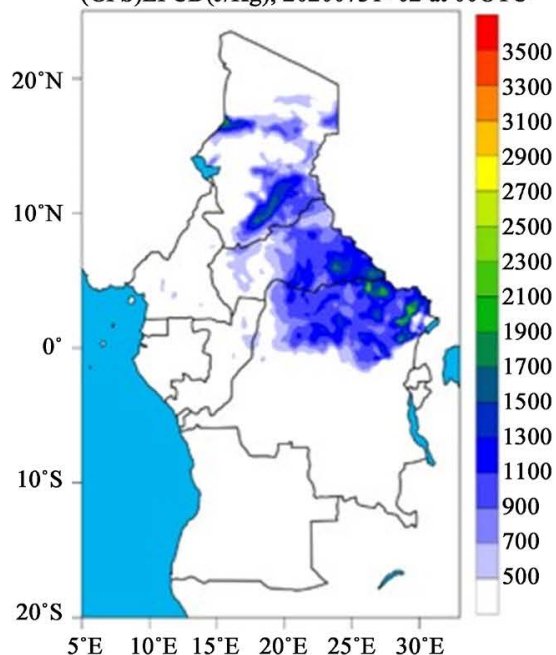

(GFS)EPCD(J/Kg), 20200731+02 at 06UTC

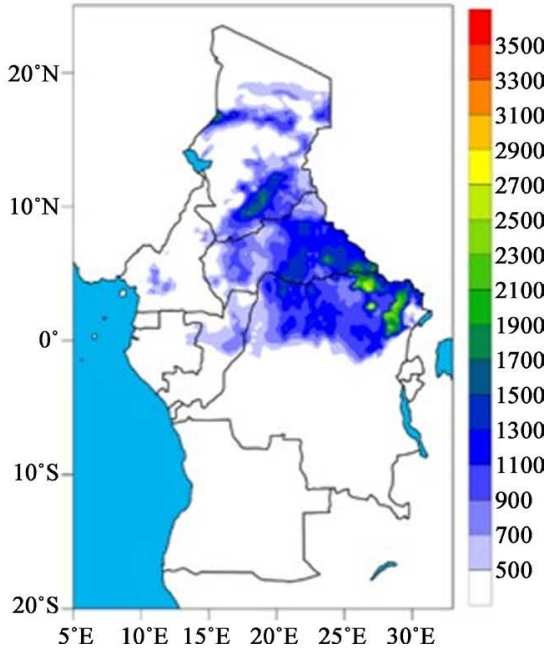




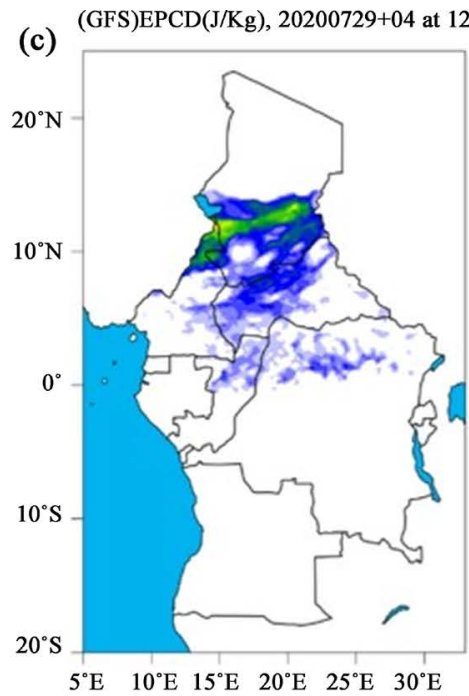

(d) $(\mathrm{GFS}) \mathrm{EPCD}(\mathrm{J} / \mathrm{Kg}), 20200729+04$ at $18 \mathrm{UTC}$

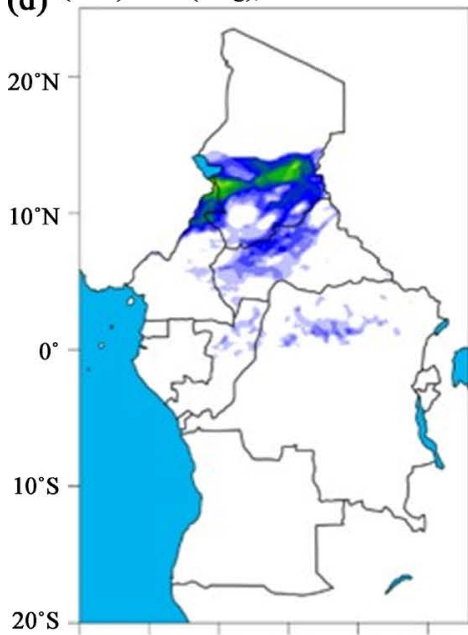

$5^{\circ} \mathrm{E} \quad 10^{\circ} \mathrm{E} \quad 15^{\circ} \mathrm{E} \quad 20^{\circ} \mathrm{E} \quad 25^{\circ} \mathrm{E} \quad 30^{\circ} \mathrm{E}$
(GFS)EPCD(J/Kg), 20200730+03 at 12UTC

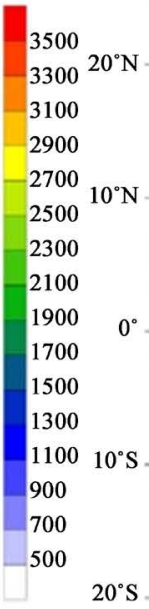

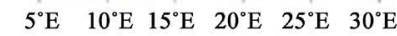

(GFS)EPCD(J/Kg), 20200730+03 at $18 \mathrm{UTC}$

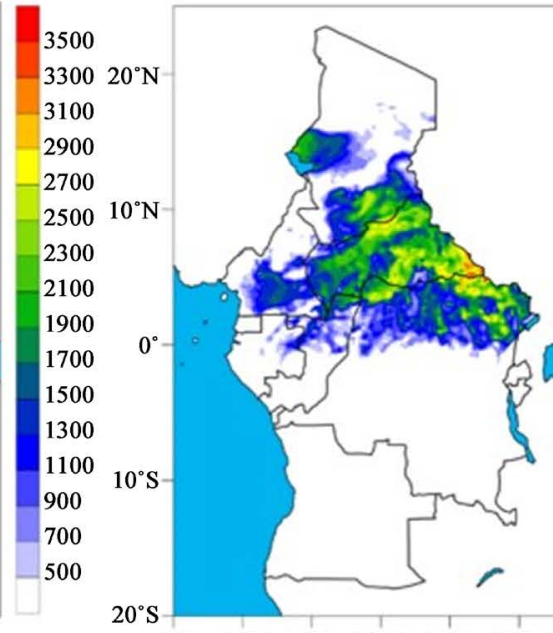

$5^{\circ} \mathrm{E} \quad 10^{\circ} \mathrm{E} \quad 15^{\circ} \mathrm{E} \quad 20^{\circ} \mathrm{E} \quad 25^{\circ} \mathrm{E} \quad 30^{\circ} \mathrm{E}$
(GFS)EPCD(J/Kg), 20200731+02 at 12UTC

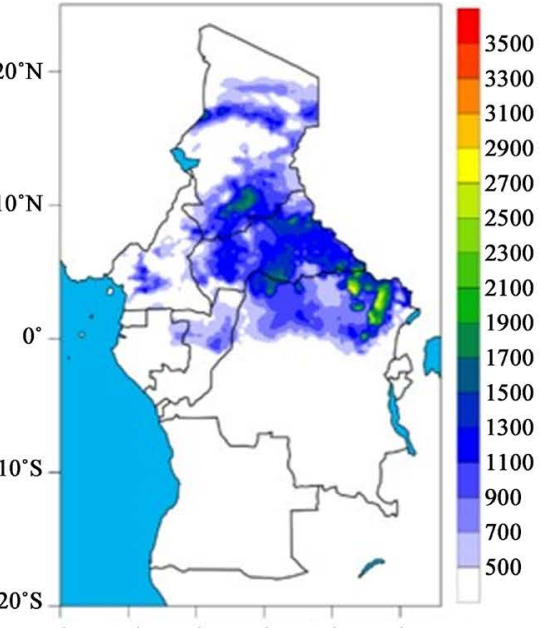

$5^{\circ} \mathrm{E} \quad 10^{\circ} \mathrm{E} \quad 15^{\circ} \mathrm{E} \quad 20^{\circ} \mathrm{E} \quad 25^{\circ} \mathrm{E} \quad 30^{\circ} \mathrm{E}$

(GFS)EPCD(J/Kg), 20200731+02 at 18UTC

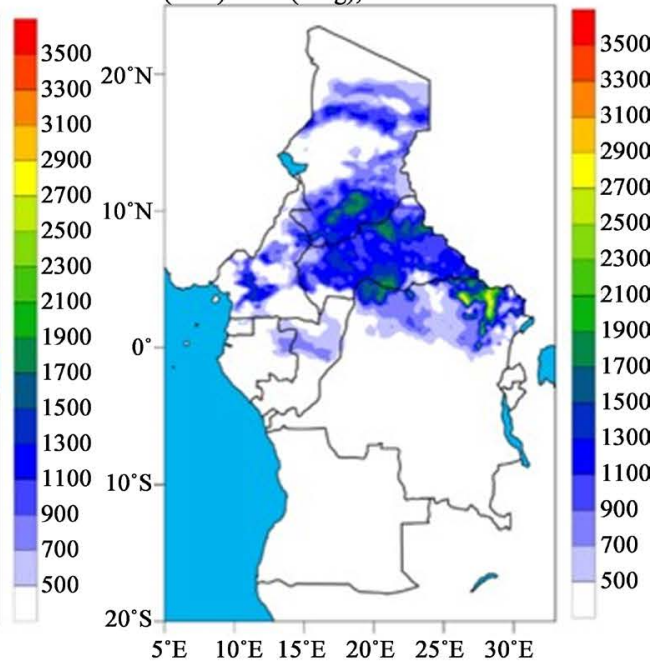

Figure 9. EPCD at 00 UTC (a), 06 UTC (b), 12 UTC (c) and 18 UTC (d).
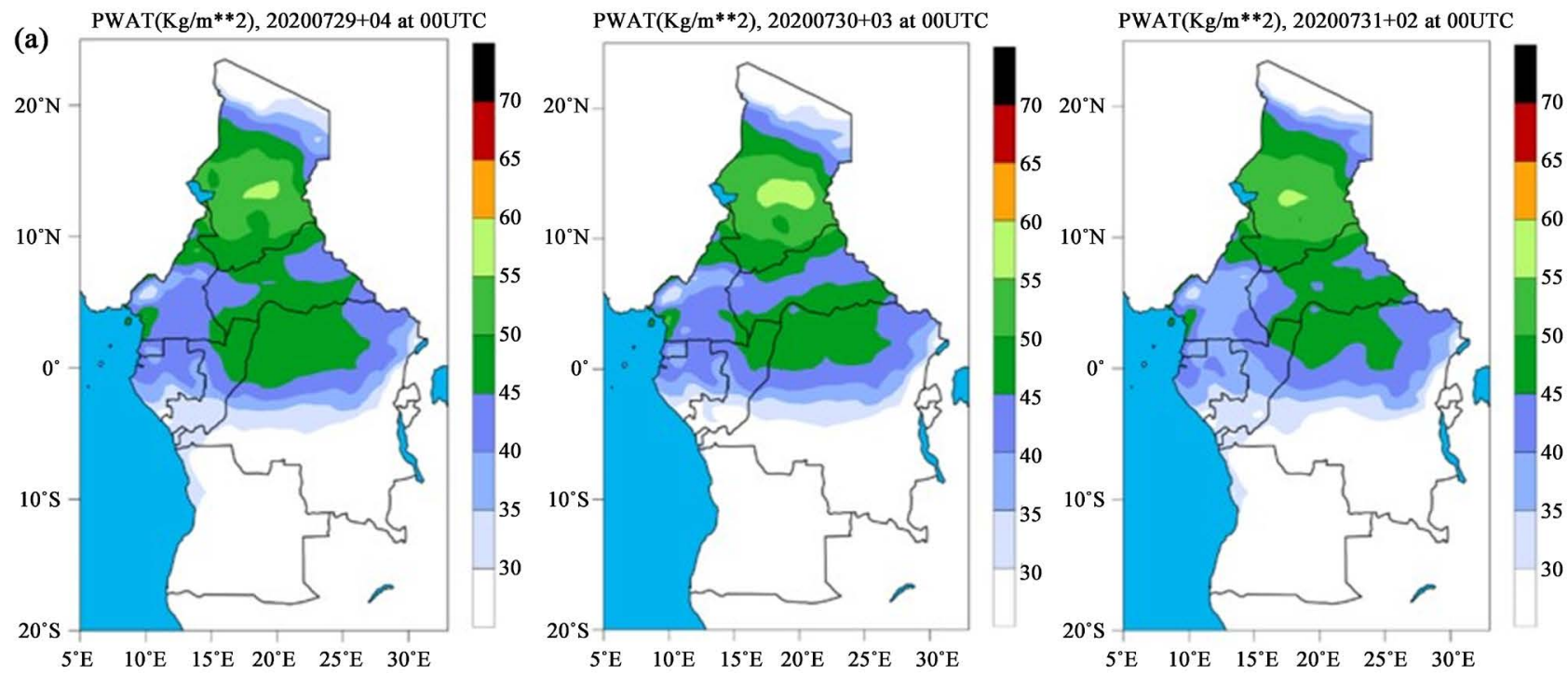
(b) $\operatorname{PWAT}\left(\mathrm{Kg} / \mathrm{m}^{* *} 2\right), 20200729+04$ at $06 \mathrm{UTC}$

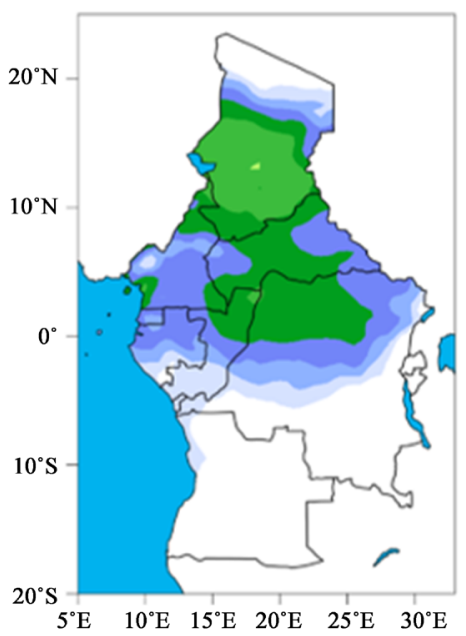

PWAT(Kg/m**2), 20200730+03 at 06UTC
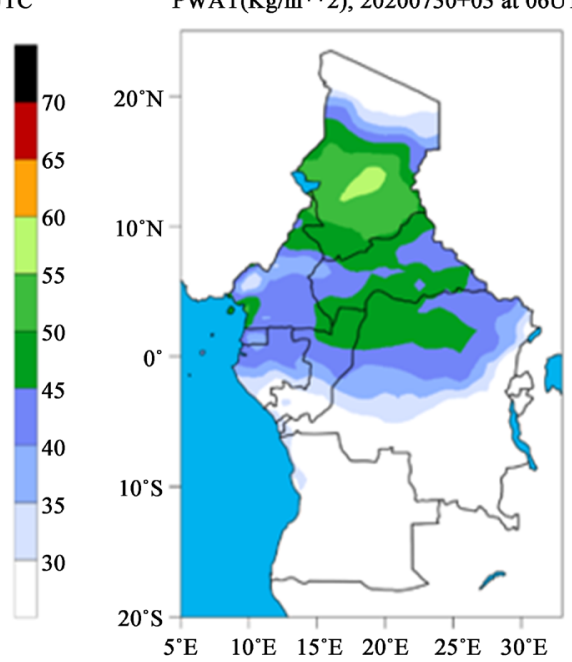

$\operatorname{PWAT}\left(\mathrm{Kg} / \mathrm{m}^{* * 2}\right), 20200731+02$ at $06 \mathrm{UTC}$

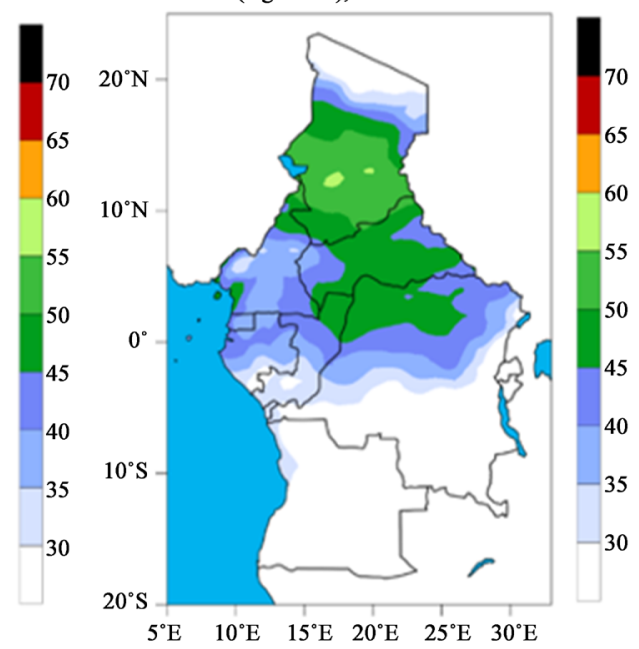

Figure 10. Precipitable water at 00 UTC (a) and 06 UTC (b).
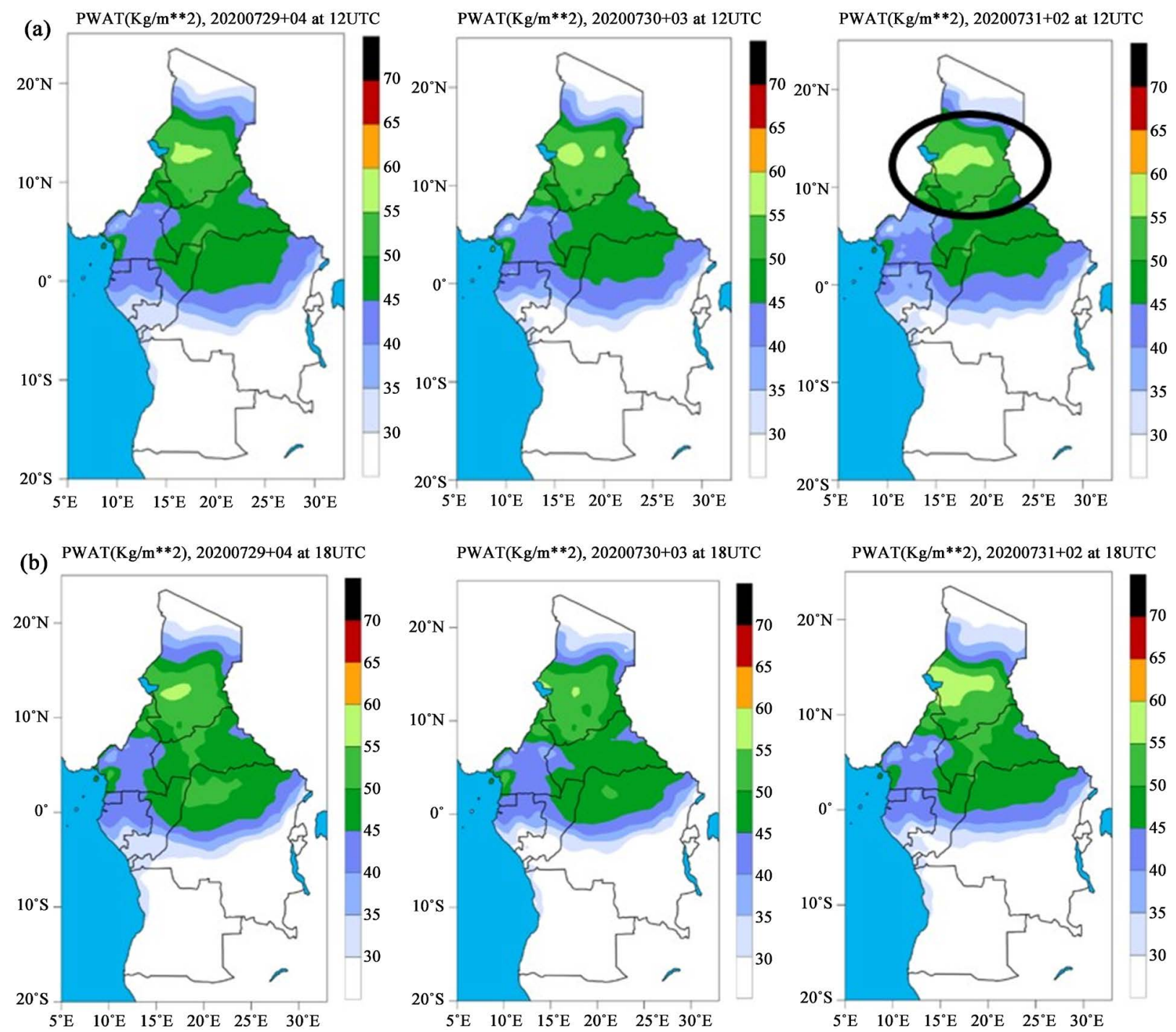

Figure 11. Precipitable water at 12 UTC (a) and 18 UTC (b). 


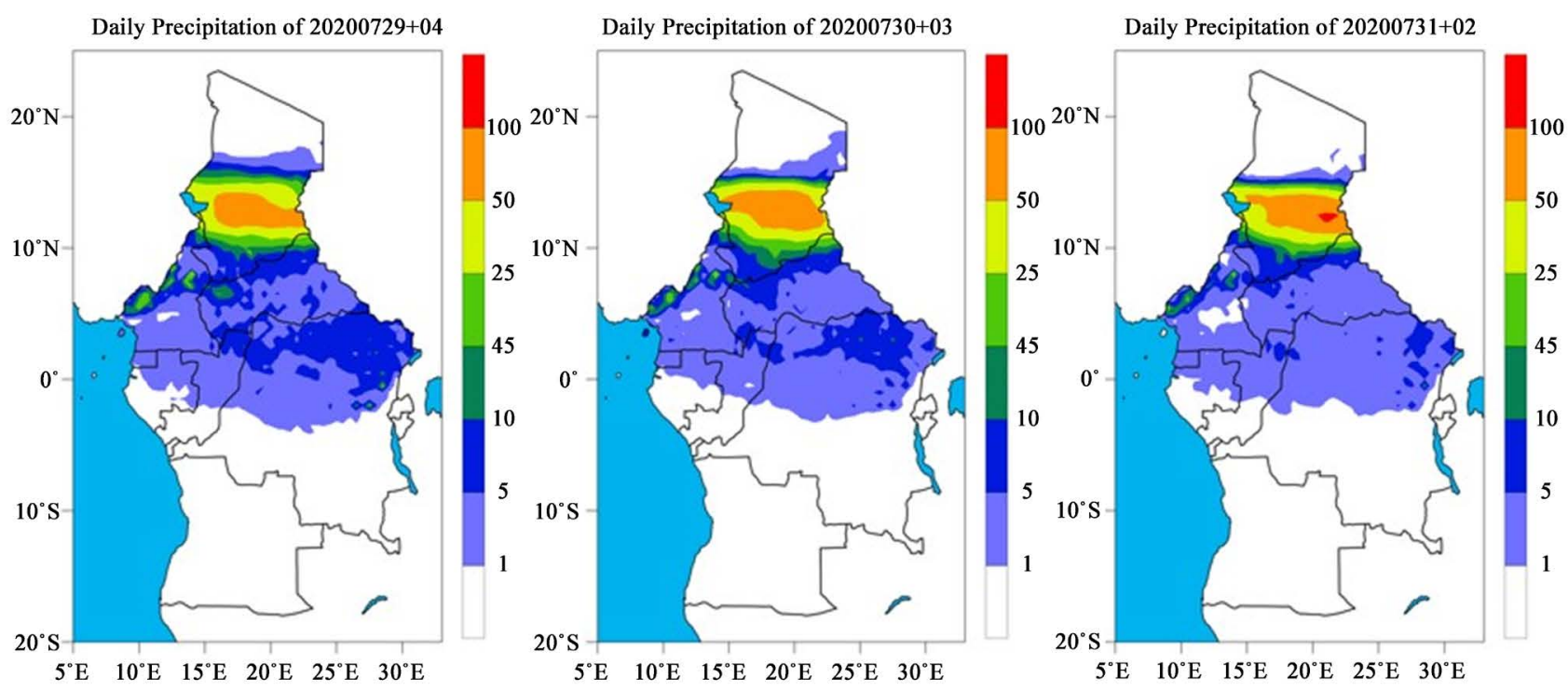

Figure 12. Daily precipitation of the day.
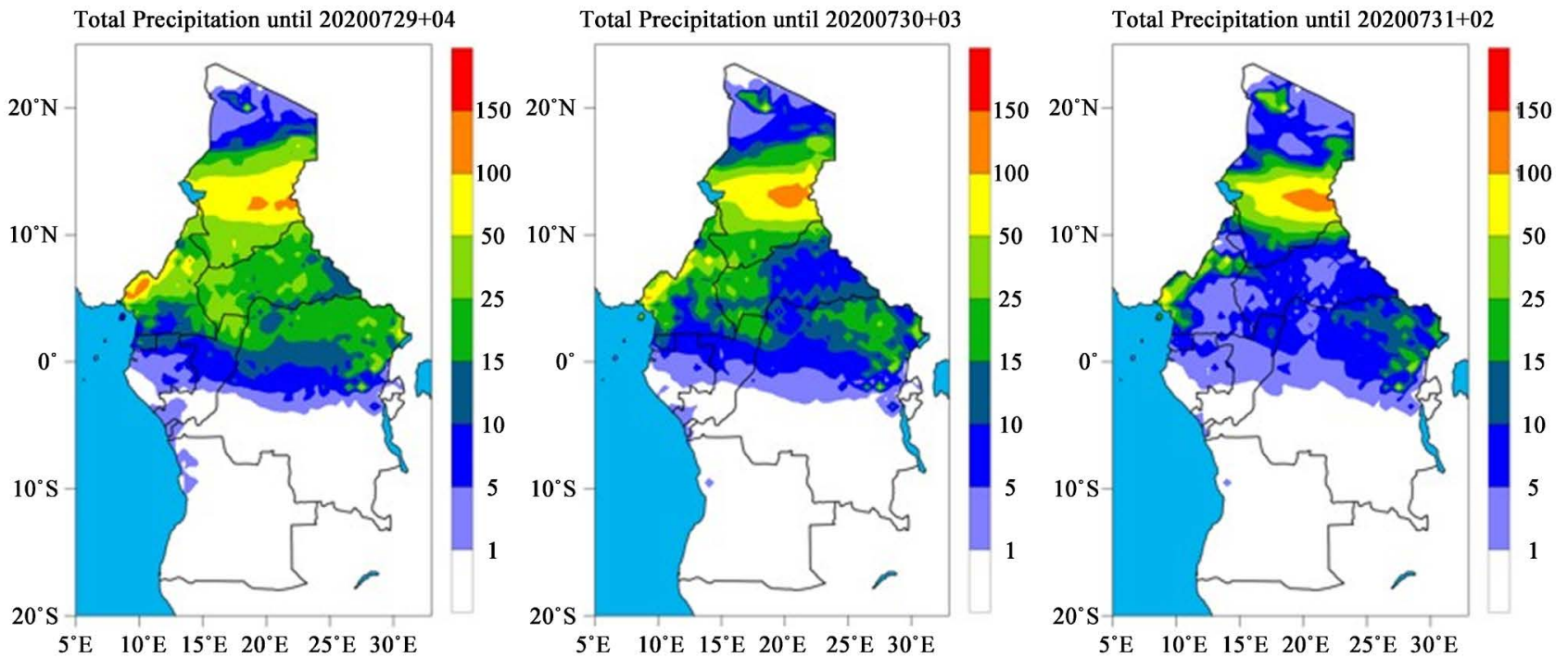

Figure 13. Total precipitation up to $00+1$ UTC.

\subsection{Rainfall Vigilance Map for the Day of August 2, 2020 in the Far North Region (Maroua-Salak) of Cameroon}

The results from the re-analyzes of model outputs are presented on the rainfall vigilance maps for the day of August 2, 2020 in the Far North region (MarouaSalak) of Cameroon. In view of these results, it emerges that the Far North region has been warned from the point of view of hydrometeorological phenomena. These dangerous weather phenomena (more or less strong impact) which generally originate in Eastern Africa, have a high impact on the Sahelian and Sudano-Sahelian zone compared to the phenomena or systems that can arise on a scale aerological or local. For this day, Figure 14 shows the Probability of occurrence and the impact of hydrometeorological phenomena on this day which varies from one spatio-temporal scale to another. 


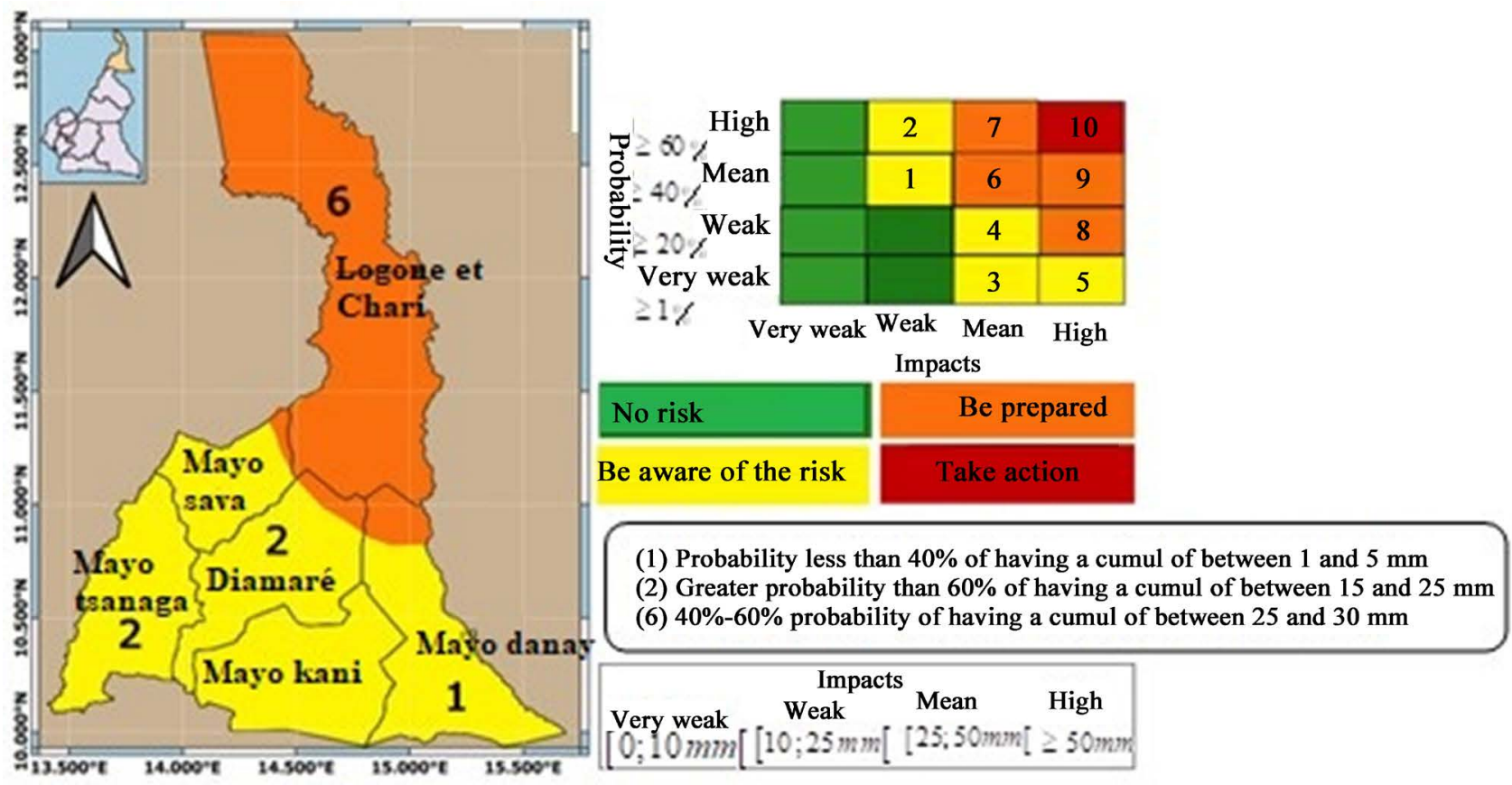

Figure 14. Rainfall vigilance map for August 02, 2020 in the Far North region of Cameroon (Maroua-Salak), valid from 00 UTC to $00+1$ UTC.

\subsection{Comparative Study of the Cumul Rainfall Obtained by the CFS, GFS and GEFS Models and by the Satellites}

In addition to their assimilation into the models, satellite data is used in the form of images. Figure 15 shows the rainfall data observed for the day of August 2, 2020 in the Far North region (Maroua-Salak) of Cameroon, estimated by 04 different satellites (IMERG Satellite, ARC2 Satellite, ERA5 Satellite and TAMSAT Satellite).

According to Figure 15, Satellite IMERG estimated the amount of precipitation to vary between 10 and $25 \mathrm{~mm}$; Satellite ARC2 in turn saw a cumul rainfall of between 05 and $20 \mathrm{~mm}$; Satellite ERA5 records a cumul rainfall of 05 to 10 $\mathrm{mm}$ and in the TAMSAT Satellite, the observed cumul amount is 05 to $10 \mathrm{~mm}$ of precipitation with a resolution of $0.03^{\circ} \times 0.03^{\circ}$ including about $03 \mathrm{~km}$ on the side.

As for the analysis of the outputs of CFS, GFS and GEFS models, the cumul rainfall provided is 05 and $10 \mathrm{~mm}$ (Figure 14).

In view of all the above, it can be seen that the result obtained by the re-analysis of the GFS and GEFS models gives an cumul rainfall which is in the interval between 10 and $25 \mathrm{~mm}$ excluded. Compared to that observed by these 04 different satellites, the majority of which confirmed the values between 05 and $10 \mathrm{~mm}$.

It is concluded that the GFS and GEFS model with a resolution of $50 \mathrm{~km}$ was able to observe what a $03 \mathrm{~km}$ high resolution satellite (TAMSAT) saw. As a result, the GFS model and the TAMSAT satellite are suitable tools that can allow the prediction of this type of disaster. 
Satellite IMERG: Cumul du 02 Aout 2020 (mm)
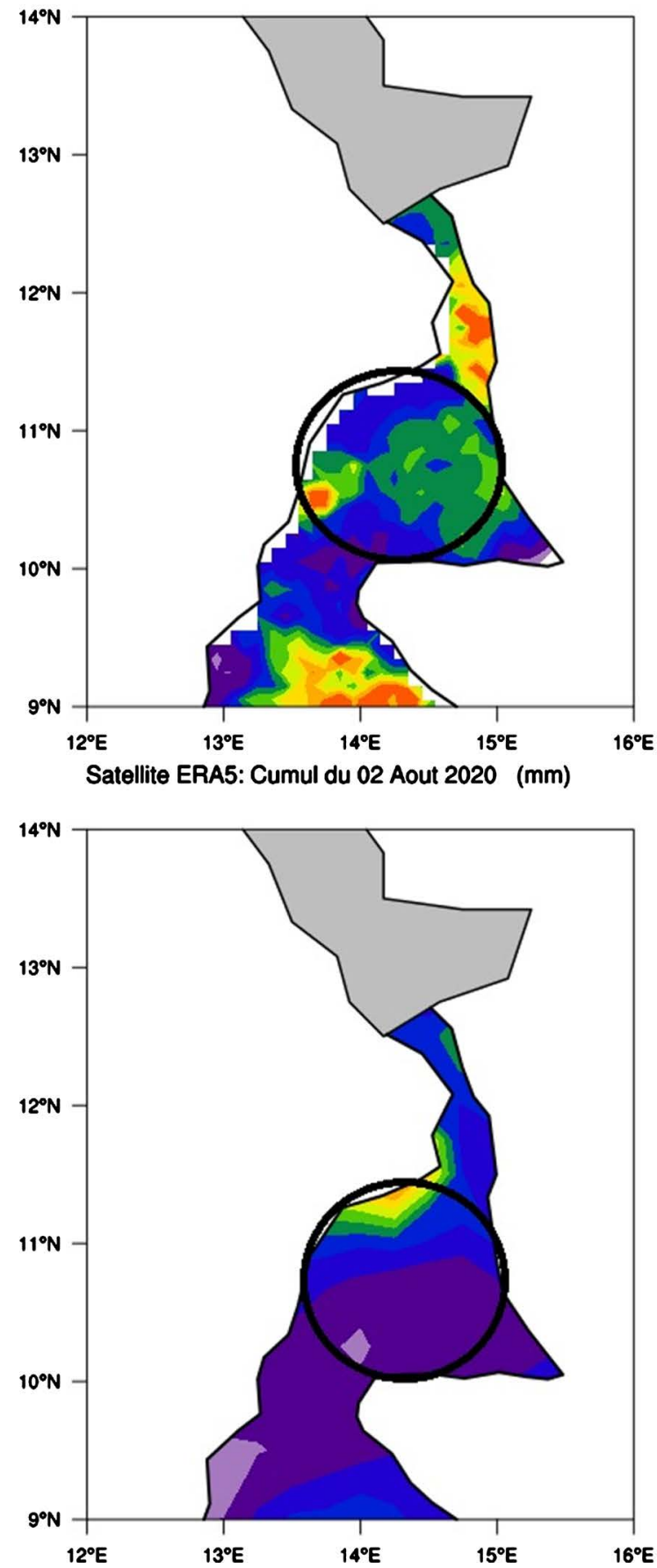

Satellite ARC2: Cumul du 02 Aout 2020 (mm)
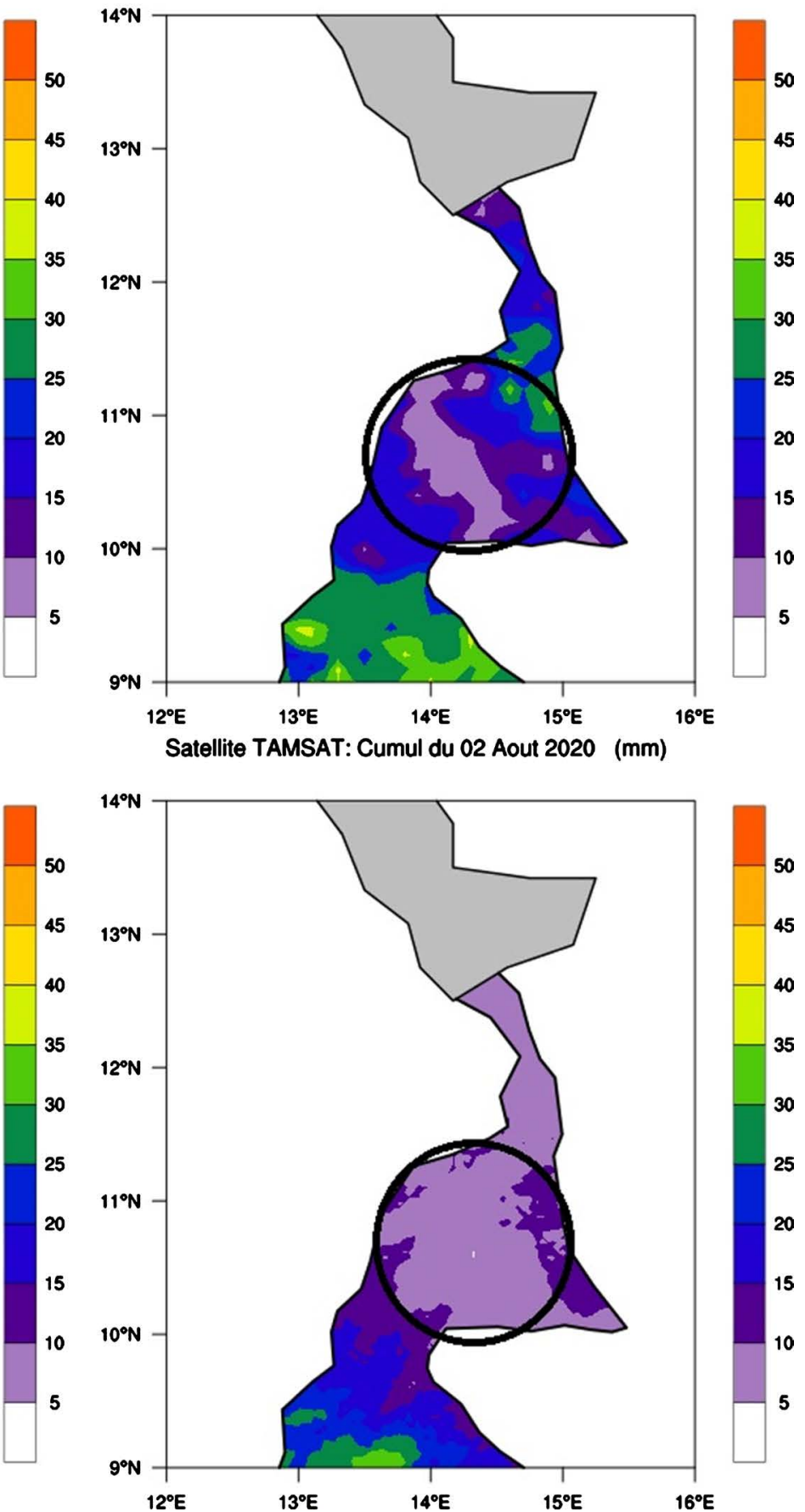

Figure 15. Precipitation observed by the satellites: IMERG Satellite (top left), ARC2 Satellite (top right), ERA5 Satellite (bottom left) and TAMSAT Satellite (bottom right).

\section{Conclusion}

The work focused on the plane crash that occurred at Maroua-Salak airport on August 2, 2020. To do this, it was a question of analyzing the weather conditions of the day using the outputs of the models (CFS, GFS and GEFS) to see if the event was foreseeable. However, the evaluation of today's weather forecast bulle- 
tin shows the presence of a hydrometeorological phenomenon (precipitation) which is a limiting factor for aeronautical activities. However, several observation methods such as Satellite IMERG, Satellite ARC2, Satellite ERA5 and Satellite TAMSAT have been used to capture this phenomenon. The use of GFS and GEFS models is better suited for predicting this type of disaster.

\section{Conflicts of Interest}

The authors declare no conflicts of interest regarding the publication of this paper.

\section{References}

[1] (2020) Le communique radio-presse No. 0473/CRP/MINDEF/019 publié le 03 août 2020.

[2] International Civil Aviation Organization (ICAO) (2008) Réglementation des services de transport aérien international. A36-WP/104/EC/14-30/8/07, $9 \mathrm{p}$.

http://www.icao.int/

[3] Lenouo, A., Monkam, D., Vondou, A.D., Tanessong, R.S. and Mkankam, K.F. (2009) Analyse des conditions météorologiques pour la sécurité aérienne à Douala. La Météorologie, 65, 46-58. https://doi.org/10.4267/2042/27951

[4] Ndongo, B., Lako, M.S. and Hiregued, J.P. (2015) Impacts socio-sanitaires et environnementaux de la gestion des eaux pluviales en milieu urbain sahélien: cas de Maroua, Cameroun. Afrique SCIENCE, 11, 237-251.

[5] Kalnay, E., Kanamitsu, M., Kistler, R., Collins, W., Deaven, D., Gaudin, L., Iredell, M., Saha, S., White, G., Woollen, J., Zhu, Y., Chelliah, M., Ebisuzaki, W., Higgins, W., Janowiak, J., Mo, K.C, Ropelewski, C., Wang, J., Leetmaa, A., Reynolds, R., Jenne, R. and Joseph, D. (1996) The NCEP/NCAR 40-Year Reanalysis Project. Bulletin of the American Meteorological Society, 77, 437-471. https://doi.org/10.1175/1520-0477(1996)077<0437:TNYRP>2.0.CO;2

[6] Kistler, R., Collins, W., Saha, S., White, G., Woollen, J., Kalnay, E., Chelliah, M., Ebisuzaki, W., Kanamitsu, M., Kousky, V., Van Den Dool, H., Roy, J. and Fiorino, M. (2001) The NCEP-NCAR50-Year Re-Analysis: Monthly Means CD-ROM and Documentation. Bulletin of the American Meteorological Society, 82, 247-267. https://doi.org/10.1175/1520-0477(2001)082<0247:TNNYRM>2.3.CO;2

[7] Han, J., Wang, W., Kwon, Y.C., Hong, S.-Y., Tallapragada, V. and Yang, F. (2017) Updates in the NCEPGFS Cumulus Convection Schemes with Scale and Aerosol Awareness. Weather and Forecasting, 32, 2005-2017. https://doi.org/10.1175/WAF-D-17-0046.1

[8] Xiaqiong, Z., Yuejian, Z., Dingchen, H., Yan, L., Jiayi, P. and Richard, W. (2017) NCEP NOTES: Performance of the New NCEP Global Ensemble Forecast System in a Parallel Experiment. Weather and Forecasting, 32, 1989-2004. https://doi.org/10.1175/WAF-D-17-0023.1

[9] Zhou, X., Zhu, Y., Hou, D. and Kleist, D. (2016) A Comparison of Perturbations from an Ensemble Transform and an Ensemble Kalman Filter for the NCEP Global Ensemble Forecast System. Weather and Forecasting, 31, 2057-2074.

https://doi.org/10.1175/WAF-D-16-0109.1 